

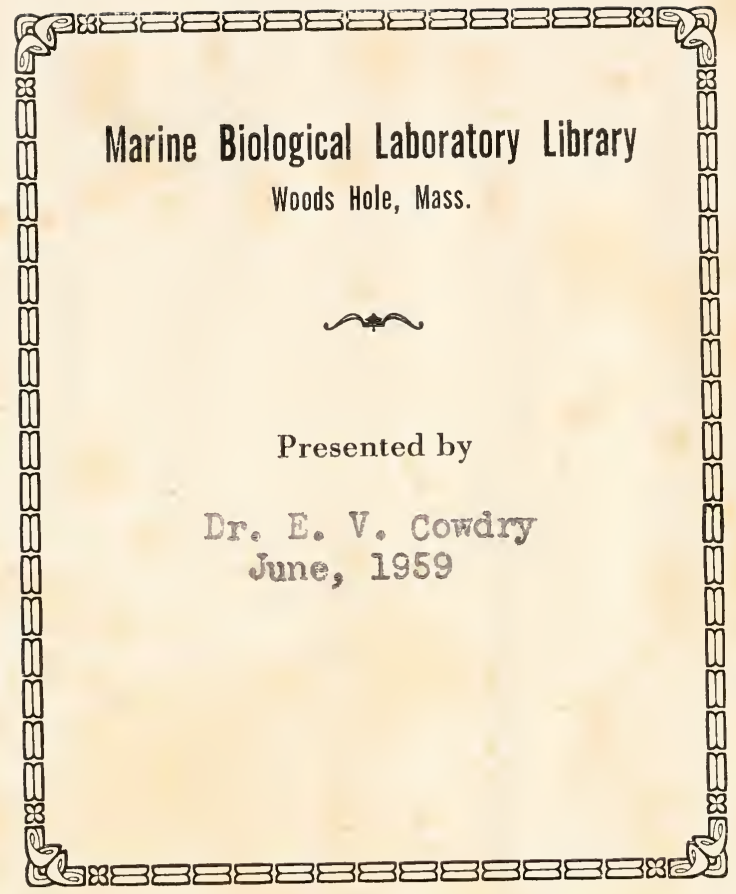




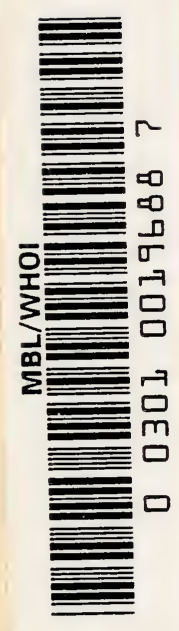




$$
(1)+5
$$




CLASSICS OF SCIENTIFIC METHOD

Edited by E. R. Thomas, M.A., M.Sc., Headmaster of the Royal Grammar School, Newcastle-on-Tyne

\section{THE DISCOVERY OF}

\section{THE CIRCULATION OF THE BLOOD}


Among other volumes to be included in "Classics of Scientific Method" are one dealing with "The Discovery of the Nature of the Air, and of its Changes during Breathing," by Miss Clara M. Taylor, B.Sc. (Headmistress of the Northampton High School and late Senior Science Mistress at St. Paul's Girls' School); and a volume on "The Impossibility of Perpetual Motion," by Mr. Alec. Wood, M.A., Fellow of Emmanuel College, Cambridge. 


\section{THE DISCOVERY OF}

\section{THE CIRCULATION}

\section{OF THE BLOOD}

BY

CHARLES SINGER, M.D., D.LitT., F.R.C.P. LECTURER IN THE HISTORY OF MEDICINE, LONDON UNIVERSITY (UNIVERSITY COLLEGE)

LECTURER IN THE HISTORY OF THE BIOLOGICAL SCIENCES OXFORD UNIVERSITY

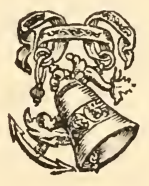

L O N D O N

G. BELL AND SONS LTD. 



\section{CLASSICS OF SCIENTIFIC METHOD}

\section{GENERAL INTRODUCTION}

"Sachez également Messieurs ... que la science dans notre siècle, est l'âme de la prospérité des nations et la source vive de tout progrès! Sans doute, la politique avec ses fatigantes et quotidiennes discussions semble être notre guide . . vaine apparence ! Ce qui nous mène ce sont quelques découvertes scientifiques et leurs applications."-PASTEUR.

THE manifold activities of the human mind in its attempt to comprehend the universe have left us a glorious heritage. The student, be he youth or adult, who wishes to trace the growth of understanding in Music, in Literature, or in the graphic arts, finds no lack of guidance. Excellent reproductions of the great masterpieces of painting or of sculpture can be obtained at small cost in volumes where the improvement in technique and the development of new ideas are indicated by a friendly hand. Scientific invention has made the study of great masterpieces of music possible to all, and there is now growing up an adequate library of musical appreciation ; while the great works of literature probably suffer from over-interpretation.

The masterpieces of Science are not, however, so accessible to those who must of necessity dwell in the outer courts of her temple. The Alembic Club reprints, Ostwald's Klassiker, and Messrs. Gauthier-Villars's Les Maitres de la Pensée Scientifique provide the specialist in various branches of science with convenient copies of 
epoch-making scientific papers, but they do not help the layman. Many educated men and women of to-day feel a desire to know more about the scientific interpretation of the external world. The specialist in one branch of science is little more than a layman in others, and he too desires a wider acquaintance with the working of the scientific spirit throughout the ages. The enlightened teacher of science realises that he has failed in his duty if he has done no more than communicate certain scientific facts to his pupils. There is, in short, a demand for a new literature of scientific appreciation.

The aim of this series is to provide reproductions of the great masterpieces of science in convenient form, together with a complete account of the action and reaction of ideas which, through the process of time, led up to the crucial experiments carried out and described by some great master. Biographical details will be introduced, and an attempt will be made to show the various social and other influences as they assist or retard the growth of knowledge. It is hoped that a reader who takes up a volume of the series, dealing with a branch of science of which he is ignorant, will be able, without further aid, to trace the steps by which the human mind has passed from chaotic ignorance to ordered knowledge.

NewCASTLE-ON-TyNE.

$$
\text { E. R. T. }
$$




\section{O N T ENTS}

PAGE

I. The Circulation of the Blood . . . I

II. The Knowledge of the Vascular System in ANTIQUity •

III. The Revival of Learning • • • • i 8

IV. Vesalius and the New Anatomy • • • 23

V. Servetus $\quad \cdot \quad \cdot \quad \cdot \quad \cdot \quad \cdot \quad \cdot \quad 29$

VI. The Successors of Vesalius • • • 37

VII. HARVEY • • • • • • • $\quad 442$

VIII. An Epitome and Estimate of Harvey's Work 50

IX. The Discovery of the Capillaries and Blood

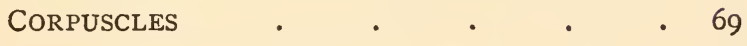

BIBLIOGRAPHY •

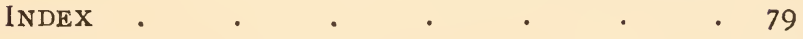





\section{LIST OF ILLUSTRATIONS}

PLATE

FACING PAGE

I. Diagram of the Circulation of the Blood • 8

II. Diagran of Galen's Physiological System a 9

III. LeONARDo. By Himself . $\quad$. $\quad$ • 22

From a drawing in the Royal Library at Turin.

Drawing of the Heart. By Leonardo • 22

From a drawing in the Royal Library at Windsor.

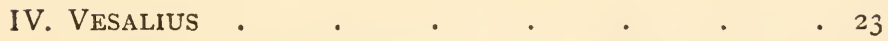

From the first edition of his Fabric of the Human Body. Basel, r543.

Servetus in Prison . $\quad$. $\quad . \quad 23$

From the statue by Clothilde Roche at Annemasse, HauteSavoie, France (four miles from Geneva).

V. William Harvey . • . . . . 42

From the painting by CoRnelius JANSSEN in the Royal College of Physicians (by courtesy of Sir D'ARCy Power).

Vi The Old Lecture Room at Padua.

(By courtesy of Professor CESARE Foligno.)

Harvey's Lecture Notes (folio 80 verso)

From the MS. in the Royal College of Physicians. 
VII. Figs. I-4. Experiments on the Bandaged Arm . 68

From Harvey's work on the circulation, printed in Frankfort in 1628 .

Fig. 5. Dissection of Vein in Thigh AND LEg . 68 From the work $O n$ the Valves of the Veins, by FABRicius, printed in Padua, r603.

VIII. Fig. i. Lungs of Frog, Showing CAPillaries . 69

From MALPIGHI's work On the Lungs. Bologna, I66I.

Fig. 2. Capillaries in the Tail of an Eel . 69

From a letter by LeEUWENHOEk, dated Delft, 1698 .

Fig. 3. Red Blood Corpuscles of Salmon - 69

From a letter by Leeuwenhoek, dated Delft, 1700.

Figs. 4 and 5. Human Red Blood Corpuscles . 69

From the same letter as Fig. 3 .

Fig. 6. Human Red Blood CoRpuscles dRawn FROM THE OBJECT UNDER A MODERN MICROSCOPE . . . . . . 69 


\section{THE DISCOVERY OF THE GIRCULATION OF THE BLOOD

\section{THE CIRCULATION OF THE BLOOD}

IF you place the finger of one hand lightly on the outer side of the front part of your other wrist you will feel a throbbing. This throbbing is called the pulse, and has been known and observed by medical men for thousands of years. The throbbing or pulsation is caused by the expansion of a tube or blood-vessel of a special type known as an artery. The expansion of the artery at each pulsation or beat of the pulse is caused by blood being forced into the artery by the special pump known as the heart.

From the heart arises a great artery, the aorta, into which the blood is pumped. The aorta is provided with valves at the point at which it arises from the heart. These valves are so arranged that they prevent any return of blood to the heart. The blood, therefore, when once forced into the aorta can move in one direction only, namely, away from the heart.

Now the aorta has many branches and, as the blood moves away from the heart, it enters them. These branches in their turn have yet smaller branches. The arteries go on branching until they get so small that they cannot be seen except with a microscope. Through all 
this system of arteries the blood can move in only one direction, always away from the heart.

At length, however, the arteries that we are tracing cease to get smaller. Instead of branching and getting smaller they now remain the same size and unite into a network of minute tubes. Nearly every part of the body is traversed by this network of tubes containing blood. They are known as the capillary blood-vessels.

The pressure of the blood in the arteries rises with each beat of the heart. As the pressure is raised, the blood, as we have seen, is forced from the heart into the aorta and onward into the other arteries. The blood moves along them and escapes into the capillaries. The effect of this escape is that the pressure in the arteries falls, until it is raised again by the next beat of the heart - and so on. If, therefore, an artery is cut or opened, the blood will escape from it in spurts, each spurt corresponding to a beat of the heart or a pulsation of the artery.

In the capillaries, owing to the extent of their network, owing to the great amount of friction due to the minuteness of the vessels, and owing also to certain other factors that we need not discuss here, the pressure of the blood is much more steady than in the arteries, and does not, as in the case of the arteries, increase and decrease in spurts. The general movement of the blood in the capillaries nevertheless continues. If you prick or cut your finger you will not usually sever an artery, but only capillaries. The result is that the blood flows from the prick with a steady ooze, and does not come out in jerks or spurts as in the case of a cut artery.

If the movement of the blood, passing always farther and farther from the heart, is traced on and on, we find that the network of minute capillaries at last unites again into larger vessels. These vessels are called veins. The veins in certain respects resemble, and in certain respects 
differ from, the arteries. They resemble the arteries in conveying the blood and in having muscular walls. They also resemble the arteries in their general distribution, for most arteries have a vein accompanying them. One difference between the veins and the arteries is that the veins tend to be larger. Moreover, the veins have much thinner and less muscular walls. They are therefore less distended by the blood that enters them from the capillaries than are the arteries by the blood that enters from the heart. As a result, the pressure in the veins is lower than in the arteries or even than in the capillaries. Blood, therefore, normally flows from the capillaries into the veins.

If the veins into which we have traced the capillaries be followed farther, we should find that they join or unite into larger veins. These larger veins in their turn join still larger veins. Finally, we should trace the veins to one very large vein, the so-called vena cava, which enters the heart.

We may now consider certain other differences between the arteries and veins. Firstly, we may note that the veins differ from the arteries in that they are equipped here and there, at irregular intervals throughout their course, with valves (Plate VII. Fig. 5). We have already seen that where the aorta arises from the heart there is a set of valves which prevents the blood from returning to the heart. Somewhat similar though less efficient valves are scattered through the course of the veins. The cusps of these valves in the veins are so arranged that they direct the flow of blood away from the capillaries and towards the heart.

Another and very important difference between arteries and veins is in the character of the blood that they contain. The blood in the arteries is bright red, and that in the veins is dark red. Blood enters the capillaries 
from the arteries a bright red colour. This colour changes while in the capillaries and the blood that leaves the capillaries and enters the veins is of a dark red colour. The presence of bright red blood in a vessel is therefore an indication that the blood is on its way from the heart and that the vessel is an artery. The presence of dark red blood in a vessel, on the other hand, is an indication that the blood is on its way to the heart and that the vessel is a vein. This fact gives rise to a simple rule for stopping the bleeding of wounds. If the bleeding is bright red it can be stopped by applying pressure above the wound, i.e. on the heart side. If the bleeding is dark red it can be stopped by applying pressure on the side of the wound away from the heart.

There is one organ in which the relation that we have described between bright red blood and dark red blood is reversed. That organ is the lung. The blood which goes from the heart to the lung is dark red, and the blood which comes from the lung to the heart is light red. We shall speak of the movement of the blood in the lung later.

Let us recapitulate. If we were to follow any particle of blood on its journey from the heart, we should find that the arteries through which it passes become smaller and smaller until the capillaries are reached. Then after passing through the capillary network, our particle of blood enters a vein from which it passes into larger and larger veins, until it finally reaches the heart again.

The heart is really a hollow muscle which acts like a pump. By contracting, as we have seen, it forces blood from its cavities into the arteries. The heart contains several cavities, but the cavity to which our particle of blood has returned is not, in fact, the same as that from which it started. To reach the cavity from which it started, the particle has to make yet another journey. 
This time its course must be through one particular and designated organ, the lung. In this second journey our particle of blood again passes through an artery which divides up, becoming smaller and smaller as it does so. The division takes place on this occasion in the lung. At last, still in the lung, a capillary network is again reached. Passing through these capillaries the particle goes on until it reaches again a small vein which passes into a larger and larger vein. Through these the particle goes on until it reaches the heart once more. Finally it arrives at the actual cavity of the heart from which it started.

To get back to its starting-point, our particle of blood has thus to go through the journey, heart-cavity, artery, capillary network, vein, at least twice. There are thus two main capillary circulations. One of them passes through the lung, and is called the pulmonary or lesser circulation. The vessels of the other capillary circulation, which we began by describing in greater detail, penetrate almost every part of the body, and this circulation is spoken of as the systemic or greater circulation.

Each of these is spoken of as a circulation, not because the movement is actually in a geometrical circle, or any figure resembling a circle, but because a circle is a figure that ends at the point at which it started. You must nevertheless remember that the word circulation should not, in absolute strictness, be applied to either of these by itself, since a particle of blood cannot get back to the actual cavity of the heart from which it started unless it passes through both circulations. There are thus, strictly speaking, not two circulations, but only one circulation.

Let us now turn to examine the different parts of the circulation somewhat more minutely, beginning with the heart itself. The heart is a very complicated structure. 
The difficulty of understanding it is largely due to the fact that the cavities which it contains are, as it were, twisted on one another in an irregular fashion and in three dimensions. It will be much easier to understand if we imagine it straightened out on a flat surface with its cavities exposed (Plate I.).

The heart contains four cavities, two on each side. The two cavities on the same side are in direct communication with one another, so that blood passes freely on each side from the upper cavity or auricle to the lower cavity or ventricle of the same side. It is important to remember that there is no communication between the auricle and ventricle of one side of the heart and the auricle and ventricle of the other side of the heart, except through the blood-vessels and capillaries. The existence of a more direct means of communication was firmly believed until the seventeenth century. This belief, as we shall see, was a very great obstacle to the advance of physiological knowledge. The removal of this belief was one of the most important events in the history of science.

From each of the two ventricles arises a great artery through which the blood is distributed. On the other hand blood is brought to each ventricle from its corresponding auricle, which in its turn receives it from a corresponding great vein. The direction of the movement of the blood is determined by a series of valves. Valves are placed between auricles and ventricles on both sides, and there are other valves at the entrance of the great arteries that arise from each of the two ventricles.

When the right ventricle contracts, blood is driven into a great artery that resembles the aorta in certain respects, and differs in others. This great artery is known as the pulmonary artery. It resembles the aorta in its muscular character, in size of its cross-section and 
in the possession of valves at its commencement, which prevent the movement of blood except away from the heart. It differs from the aorta in being much shorter and breaking up much sooner into branches, though these facts cannot be brought out in a diagram. It also differs from the aorta in supplying branches only to the lung instead of to all parts of the body.

In the lung the branches of the pulmonary artery, like the branches of the aorta, break up, as we have seen, into a capillary network. The pulmonary capillary network, again like the systemic capillary network, passes into veins. These veins in the lung unite and become larger and larger until they all end in a great trunk, the pulmonary vein, which opens into the right auricle.

We have compared the pulmonary artery to the aorta, and referred also to certain points of difference. There is, however, one great difference between the pulmonary artery and the aorta that was a very great puzzle to the ancient physiologists. The nature of that difference is, however, quite clear nowadays. The pulmonary artery contains dark red blood, the aorta contains light red blood. This fact is easily understood if we examine how the blood reaches these two great vessels. We have already seen blood changed from light to dark in the systemic capillaries, and passing from them into the veins, thence into the vena cava, thence into the right auricle, thence into the right ventricle, and thence into the pulmonary artery. The pulmonary artery branches and breaks up into capillaries in the substance of the lung. In these pulmonary capillaries the change that took place in the systemic capillaries is reversed. Dark red blood enters the pulmonary capillaries and it emerges from them light red. From the pulmonary capillaries this light red blood passes into the pulmonary vein. The pulmonary vein conveys it to the left auricle, 
whence it passes to the left ventricle and from thence the light red blood is forced into the aorta and systemic circulation.

These alterations of colour from light to dark and from dark to light are indications of chemical changes. They are due to the chemical combination of the red substance of the blood with oxygen in the case of the light blood, and with carbon dioxide in the case of the dark blood. The nature and meaning of this change will be discussed in a companion volume of this series dealing with respiration. In this book we shall only consider the movement of the blood from a mechanical point of view.

Let us now again trace a particle of blood on its journey. This time we can follow it through the entire circulation. Leaving the left ventricle, when the walls of that cavity contract, the particle is forced through the valves into the great artery known as the aorta. From the aorta it passes into smaller and ever smaller arteries, finally reaching the systemic capillary network. After travelling through that network it enters a vein. Thence it passes into larger and ever larger veins, until it ultimately enters the great vein known as the vena cava that opens into the right auricle. It has now completed the systemic circulation. As the right auricle contracts, our particle of blood passes through the valves between the right auricle and right ventricle into the right ventricle. From there it passes into the great pulmonary artery, which conducts it to the lung. In the lung the pulmonary artery breaks up into branches and finally into capillaries. Through these our particle travels until it reaches a tributary of the pulmonary vein and finally the pulmonary vein itself. The pulmonary vein empties its blood into the left auricle, carrying our particle with it. From the left auricle the particle of blood passes at last into the left ventricle, from which it started. 


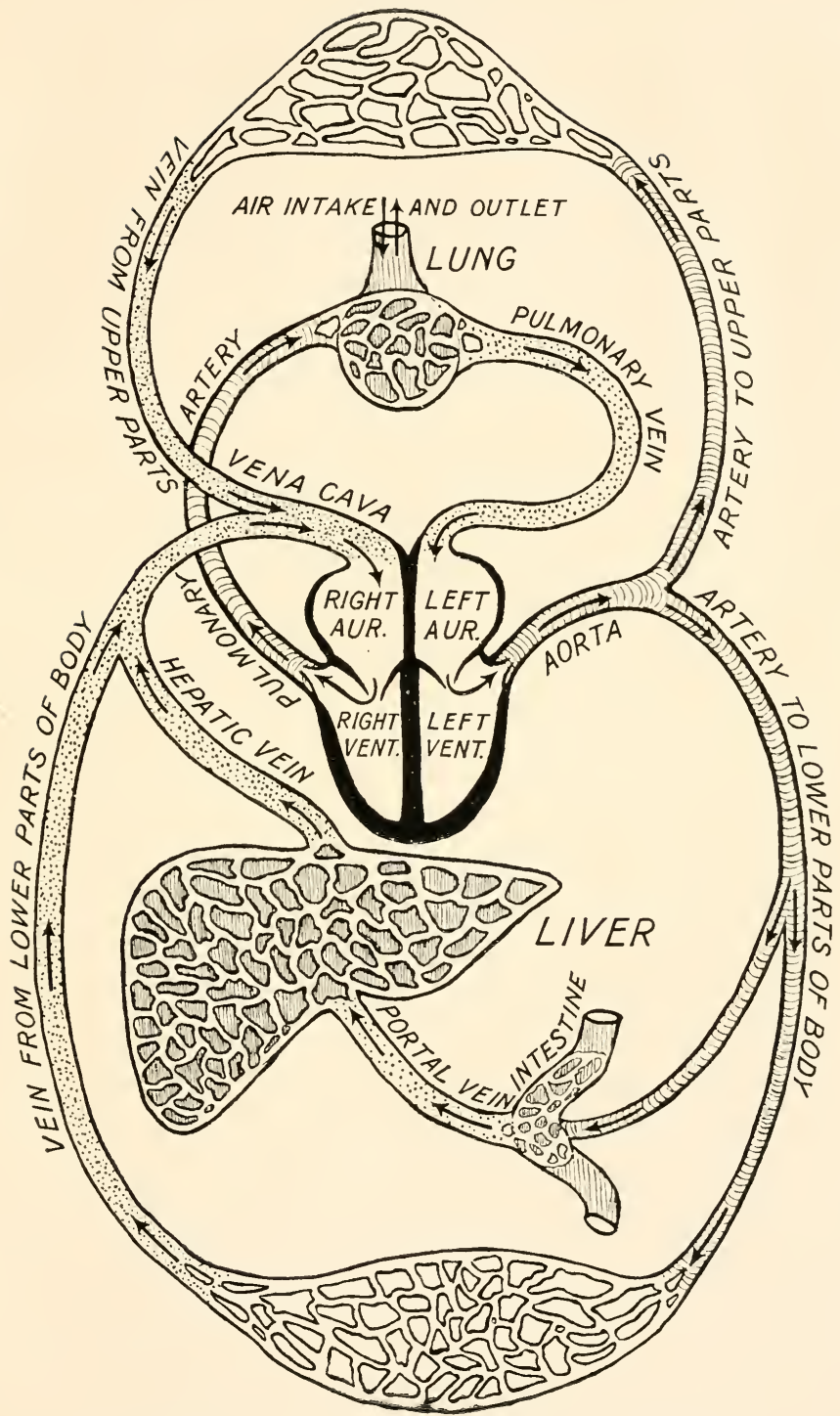

Diagray of the Circulation of the Blood. 


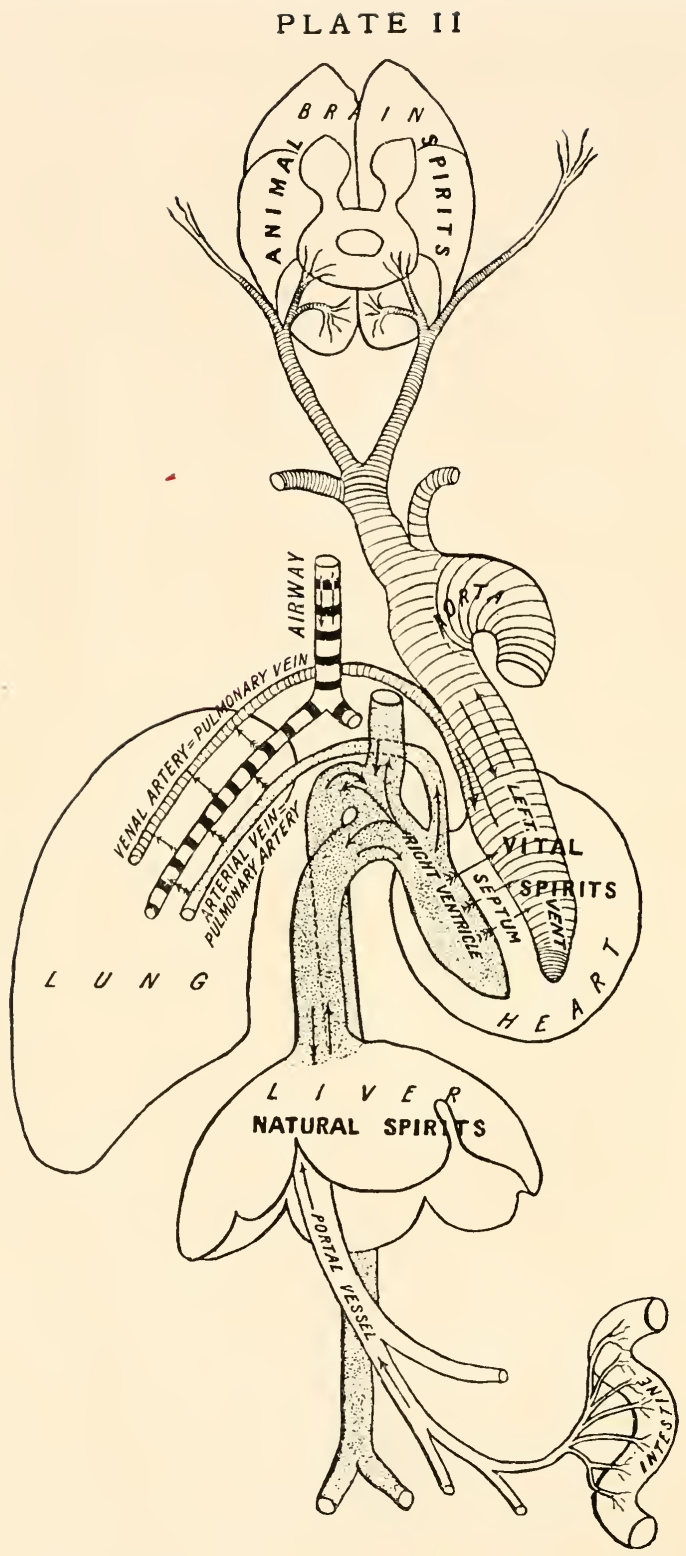

Diagram of Galen's Physiological System. 
This is only a very rough description of the circulation of the blood. It leaves out of account some very important factors, such, for instance, as the movements of the chest wall during breathing, and in general the effect of respiration on the circulation. It leaves out of account also the fact, which may be gathered from the diagram (Plate I.), that the veins from certain organs, as, for example, the intestine, break up into capillaries for a second time before returning to the heart. Bearing these omissions in mind, however, we may turn to a discussion of the process by which it was discovered. This discovery was the work of an Englishman, William Harvey. Before we can understand his work we must learn something of what men believed before his time concerning the action of the heart and blood-vessels. 


\section{I}

\section{THE KNOWLEDGE OF THE VASCULAR SYSTEM IN AN'TIQUITY}

THE pulse is the most obvious activity of the circulatory or, as we may call it, the vascular system. Even in very ancient times physicians had noted its existence and observed its variations. Thus in an Egyptian medical papyrus, written about I 500 B.C., the pulse is mentioned, and we learn that its character and force, size and frequency, were even then considered to give an indication as to the state of a patient's health. The Egyptian papyrus considers that the pulse is related to the bloodvessels.

Outside Egypt also physicians attached great importance to the pulse. In the writings of the Asiatic Greek physician, Hippocrates of Cos, who lived about 400 B.C., we find that the pulse is considered to be due to movements of blood-vessels, and that these have been traced to the heart. As the pulse was even then constantly being examined by medical men, this view made them take much interest in the heart and blood-vessels. Physiological systems were therefore very early drawn up, based on the relationship of the heart and vessels to the pulse.

The best known of these systems is that of the Greek philosopher and naturalist, Aristotle, who taught at Athens, and died in the year 32.2 B.C. Aristotle was one of the best observers of nature that have ever lived, but 
he made some unfortunate mistakes concerning the vascular system. Thus he attached enormous and exaggerated importance to the heart. Not only did he and his successors rightly regard it as the centre of the vascular system, but they also attributed to it various other qualities and functions that we now know it does not possess. They regarded the heart as the seat of the intelligence and the source of the bodily heat. Moreover, they considered that, during the process of development, the heart was the first organ to develop, while at death it was the last organ to show activity. These views have since been shown to be erroneous.

Soon after the time of Aristotle, and about 300 B.C., a great medical school was founded at Alexandria in Egypt. That country had been conquered by Alexander the Great, after whom the town Alexandria was named. On Alexander's death, Egypt came under the rule of one of his generals, Ptolemy, who founded a dynasty which became extinct in the time of Julius Cæsar with the famous Queen Cleopatra, just before the Christian era.

The town of Alexandria, though in Egypt, was a favourite residence of this Greek dynasty, and became more Greek than Egyptian. Ptolemy and his successors were disposed to encourage learning, and at the medical school at Alexandria very remarkable physiological researches were made. These were entirely the work of Greek physicians, and by them the knowledge of the heart and the vascular system was placed on a more scientific basis. Thus there arose in Alexandria a tradition of physiological learning and research that was to be found nowhere else in the ancient world.

About the middle of the second century A.D. there came as a student to the still flourishing medical school at Alexandria a young Asiatic Greek, whose views were 
destined to exercise the most profound influence on the course of science. His name was Galen, and he became one of the most eminent exponents of science in all antiquity. Galen afterwards practised for many years at Rome, and became the medical attendant to the Roman Emperor, Marcus Aurelius. He died in the year 2.00 A.D. His account of the vascular system is of great importance for our subject.

Galen's views on the nature and action of the heart, the blood-vessels, and the pulse remained current for some fifteen hundred years, and all references to the nature and action of the heart, the blood, or the pulse in older English writers-for example, in Chaucer or Shakespeare - can be traced to interpretations of Galen's works. The ideas of Galen are therefore of more than historical interest. An understanding of them is necessary not only for the history of science, but also for the explanation of many allusions in literature and not a few colloquial expressions. We shall therefore turn at once to a discussion of Galen's physiological views.

Galen taught (Plate II.) that the body was governed by three principal structures that formed a sort of aristocracy among the organs of the body; these were the liver, the heart, and the brain. Ingested food passed into the intestines and was absorbed from there as chyle, and carried by the portal vessel to the liver. In the liver this chyle was elaborated into blood, and charged with an imaginary essence, the natural spirits. The presence of these imaginary natural spirits was supposed to be necessary for the continuance of even the lowest form of life.

The natural spirits were distributed from the liver to the various parts of the body, and they were sent thither by means of the veins. The liver was thus regarded by Galen as the centre of the venous system. The veins 
sent blood charged with nourishment, absorbed from the intestines, together with natural spirits absorbed from the liver, to all parts of the body. In the veins this nutritive blood was thought to ebb and flow, up and down. During this ebb and flow, the veins absorbed into their blood impurities from all parts of the body. No idea of circulation was involved. A large branch of the venous system entered the right ventricle.

Two parts of this venous system are of special interest to us for the understanding of Galen's ideas. One was the vessel that he called the arterial vein which goes to the lung. It is the structure we now call the pulmonary artery. This vessel when it reached the lung discharged, as he thought, all the impurities that had been brought by the venous system from the various parts of the body. The impurities passed into the airtubes of the lung, and were thence exhaled into the outer air. Galen knew that animals could not live indefinitely in a closed space, and died if so confined. This event was thought by him to be due to the impure and poisonous substances conveyed by the breath to the air.

The second branch or rather series of branches of Galen's venous system that are of special interest for our purpose had no real existence. They were entirely a product of Galen's imagination. Their existence, however, was firmly believed for many centuries, and this belief was one of the main obstacles to the true explanation of the action of the heart. Galen thought that some of the blood which entered the right ventricle passed through the muscular wall or septum that lies between the two ventricles, and so reached the left side of the heart. Now it happens that on the walls of the septum which face the cavity of the two ventricles are a large number of blind pits. It was believed that these pits represented a series of minute passages from one ventricle of the heart 
to the other. Although a seeker, or even a fine bristle, cannot be made to penetrate from one ventricle to the other through any of these pits, yet for ages, and in spite of the evidence of their senses, men continued to believe that these channels really existed. The great Galen had believed in their existence, and that was enough! If they could not be found, it was thought that it was because they were so small that they were beyond the reach of vision. Their existence was necessary to explain the nature of the heart's action. It must be remembered that there were then no microscopes or lenses to increase the power of vision, so that it was the easier to believe in the existence of these channels. Furthermore, no better explanation of the physiology of the heart than that provided by Galen was forthcoming for very many centuries.

We have now to consider what Galen and his followers believed to be the fate of the small amount of blood that made its way, as they thought, drop by drop, through this septum by means of the imaginary passages. Galen knew well of the difference in appearance between arterial and venous blood, he fully recognised the light colour of the blood in the arteries as compared with the dark colour of the venous fluid. Though he had no clear idea of the nature of respiration, though he knew nothing about the composition of the atmosphere, and though oxygen had not yet been discovered, yet he attributed this difference between the arterial and venous blood to a cause not very different from that assigned to it to-day. He considered it was the action of the air that produced the lighter colour of the arterial blood.

Galen knew too of the existence of the important vessel that empties itself into the left auricle which we call the pulmonary vein, but which he called the venal artery. We know now that this vessel brings oxygenated 
blood to the heart, and he knew that it carried something to the heart and had an important part to play in altering the character of the blood. He seems to have believed, however, that it did not bring aerated blood to the heart but air only, and that this air it drew from the cavities of the lung. He regarded this vessel as a branch of the arterial system, and it was on this account, recognising the thin and vein-like character of its walls, that he called it the venal artery. Galen paid very little attention to the auricles, regarding them merely as dilatations at the entry of the great veins into the heart. He therefore described the heart as having only two cavities, the two ventricles. The air carried by this pulmonary vein, or venal artery, as he called it, entered, Galen thought, the cavity of the left ventricle. There it met with the trickle of blood that came through the supposed channels in the septum, and by its combination with this trickle of blood of venous origin he believed that arterial blood was produced. An important feature of the arterial blood was the presence in it of a second kind of spirits, the so-called vital spirits. These spirits, derived from the heart, differed from the natural spirits derived from the liver. The vital spirits were responsible for all kinds of movement and muscular activity. Arterial blood carrying its charge of vital spirits was distributed by the arteries to all parts of the body.

We need not, for our purposes, follow it there, but we may glance for a moment at one group of arterial branches that Galen considered were of special interest. Some of the arterial blood naturally reached the brain, where, according to Galen, it was charged with a third kind of spirits, the animal spirits. These animal spirits, like the other forms of spirits, Galen believed to be also distributed to different parts of the body. The animal spirits, however, were, it was thought, separated from the 
blood, and sent out to the body as a sort of nervous fluid. The distribution of this imaginary fluid took place through the nerves, which were regarded as hollow. The animal spirits were held responsible for all the kinds of activity that we call nervous.

To return to the blood itself we may emphasise that Galen's view of the action of air on the blood was not wholly imaginary. It was grounded on observation in so far as it took account, firstly, of the necessity of air for life; secondly, of a real difference between venous and arterial blood; thirdly, of the fact that the systems in which both kinds of blood, arterial and venous, are contained have direct connection with the heart; and fourthly, of some relation to the warmth of the body, the supposed nature of which we must now consider.

Long before Galen's time physicians had come to associate heat with life. They had observed that animals grew cold when dead, while living animals remained warm without the aid of any apparent fire. They thus thought that the animal heat produced without fire was a special property of living matter and was different from the heat that was derived from fire. It was therefore given a special name and called the innate heat. The innate heat was held to be developed specially by the heart, an organ on which, as we have seen, great stress had been laid by Aristotle, who lived five hundred years before Galen. The name of the great naturalist, Aristotle, thus became connected, in the minds of later writers, with the idea of this mysterious innate heat. The connection of so important a name as that of Aristotle with this idea had very important effects in a later age.

Galen, however, was dissatisfied with the current view of the innate heat. He refused to accept its peculiar and inexplicable nature, and he sought to explain it and to bring it within his physiological system. He 
ventured to compare the action of the heart to that of a fire or furnace. The air taken to the heart by means of the venal artery (our pulmonary vein) was combined, as he thought, with the blood in the left ventricle to form the animal spirits that were, in his view, such an important feature of the arterial blood. In the process something akin to combustion took place, and heatthe animal heat that was the sign of life-was given off. This made the heart the hottest organ of the body. Its heat was, however, regulated and controlled, as he thought, by the very agent that fed it. The mechanism for this regulation and control was placed by Galen in the lung. Air entering the lung kept that organ, it was thought, at a low temperature, the superfluous heat being got rid of by the warm breath. The lung was thus enabled to act as a sort of cooling bath to the heart. Respiration, in the Galenic view, thus became a mechanism for regulating the heat of that furnace, the heart. If too little air were taken in, the furnace might be damped down and even put out. If too much air were taken in, the flame was fanned, combustion became fiercer, and the heat increased as in fever. If a great deal too much was taken in, the furnace might be blown out as effectively as it might be suffocated by too little air. 


\section{I I}

\section{THE REVIVAL OF LEARNING}

DuRING the Middle Ages the beliefs about physiology were always based on Galen. They were frequently confused and often the result of a misunderstanding of his work. In the fifteenth century, however, took place the so-called Renaissance or Revival of Learning. Greek works began to be recovered and to be more accurately studied. The first step towards any improvement on the views of Galen was naturally a proper understanding of what he really said. For that purpose a correct knowledge of Greek was needed, and such a knowledge had been exceedingly rare in the Middle Ages. In the fifteenth century, however, knowledge of this kind became more common. It was an age of enthusiasm for the Classics and of revival of classical scholarship. Accurate translations of the Greek works of Galen were made. The printing-press was invented about the middle of the fifteenth century, and towards its end printed copies of the new translations of the works of Galen began to be distributed all over Europe. So it came about that the Revival of Learning was coincident with a Revival of Science.

An indication of this scientific revival was a new interest in dissecting. Even during the Middle Ages there had been a certain amount of dissection in connection with medical courses at the Universities. At first this dissection was undertaken merely with the 
object of verifying Galen's views. The professor read out the text of Galen, and the students looked on the dissections as merely a method of making it rather easier to remember what Galen had said. The dissection, in fact, was supposed to illustrate Galen, rather than Galen to explain the dissection. It was nearly the middle of the sixteenth century before there was any real and open discussion of Galen's views in the Universities.

But there were also other influences at work. Along with this Revival of Learning and Revival of Science there was also a Revival of Art. Every one has heard of the names of some of the great artists of the Renaissance - Michelangelo and Raphael for instance. These artists, and many like them, began to study the human form very closely. They soon found that to represent it accurately some knowledge of anatomy, and especially of the bones and muscles, was needed. The artists, therefore, also began to dissect.

Now among these great artists were some who took more than a purely artistic interest in the structure and functions of the parts of the body. The best known of these, and the most interesting for our purposes, was Leonardo da Vinci, who lived from 1452 to 1518 . Like most of the great artists and scientists of the period he lived in northern Italy. His work was done chiefly at Florence and Milan. Leonardo was an artist, but he was also a great deal more. He was a man of enormously powerful and inquiring mind, and his achievements in Science are at least as remarkable as his eminence in Art. He had determined to write a text-book of anatomy and physiology. Though he did not live to publish it, some of his beautifully illustrated notebooks on these subjects have survived. They enable us to form an idea of what a magnificent work it would have been. We shall here 
consider some of his researches which bear upon the heart and the organs of respiration.

Leonardo was the first man to question the views of Galen. He made most careful first-hand investigations on the bodies of men and animals, and he performed many physiological experiments. It happened that he was particularly interested in the heart and vascular system. In the course of his researches he came to the correct conclusion that the branches of the air-tubes in the lungs, the bronchi, as we call them, branch and gradually diminish in size and finally end blindly. He inflated the lungs with air, and found that whatever force he used, he was unable to drive the air from the bronchi into the heart. He therefore inferred quite correctly that Galen's venal artery (our pulmonary vein) did not convey air to the heart as the followers of Galen believed that it did.

Leonardo then turned to the examination of the heart itself. First he examined its structure and form, and prepared more accurate drawings of it than had been made by any before him (Plate III.). Then he made sections and dissections of it, and examined its valves. He observed and carefully figured the four cavities of the heart-the two ventricles and the two auricles. Galen had known the ventricles, and had attached much importance to them ; the auricles, as we have seen, had been almost entirely neglected by him, as he considered that their only function was to prevent over-distension of the ventricles. Galen thus described the heart as having only two cavities. Leonardo correctly described it as having four.

Of all the bodily movements, Leonardo evidently found those of the heart and vascular system at once the most perplexing and the most absorbing. To the question of their nature he returned again and again, expending on it much of his time, his art of dissection, his keen observa- 
tion, and his knowledge of the laws of physics. His drawings, experiments, and deliberations tell their tale of his unceasing efforts to reach a solution of this abstruse problem. Leonardo ultimately succeeded in grasping quite clearly the nature and action of the valves at the root of the great arteries, and he verified his views by most remarkable experiments. He proved conclusively that the valves allowed the blood to pass in only one direction, and prevented its regurgitation.

Leonardo, however, gave no complete or clear description of the vascular system as a whole. He was not able entirely to emancipate himself from the old idea of the passage of the blood from the right ventricle through the septum into the left ventricle, although he sometimes seems doubtful about the truth of it, for he emphasises the fact that the pores in the septum are invisible. One must remember, however, that Leonardo has not left us any systematic account of the subject; his remarks are distributed over many years and many manuscripts. Nor is it surprising that Leonardo, who was no physician, should be incomplete and obscure in dealing with one of the most difficult physiological problems. It is also to be remembered that Leonardo did not publish the results of his research-it is only comparatively recently that they have been found in his manuscripts.

But although Leonardo's works remained in manuscript, it must not be assumed that he did not influence his contemporaries and successors. At any rate, soon after his time it is evident that the questions that he had raised concerning the heart and blood-vessels were attracting others, and were generally regarded as an important problem needing solution. This in itself shows that men were beginning to doubt the basis of the current physiological views which were still those of Galen. Thus Jacob Berengar of Carpi, who died twelve 
years after Leonardo, and who, like him, worked in northern Italy, was at work on the same topic. He, too, was carefully investigating the valves of the heart, and was greatly puzzled as to their action. He saw that they would admit blood only in one direction, but he also failed to carry the matter further. 


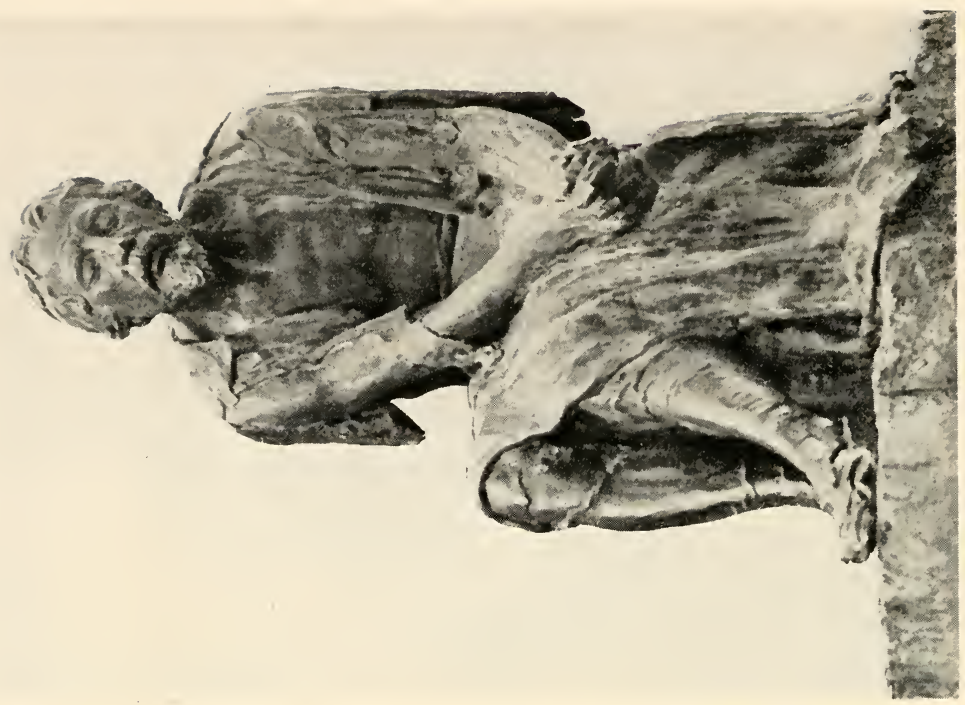

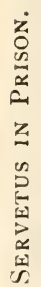

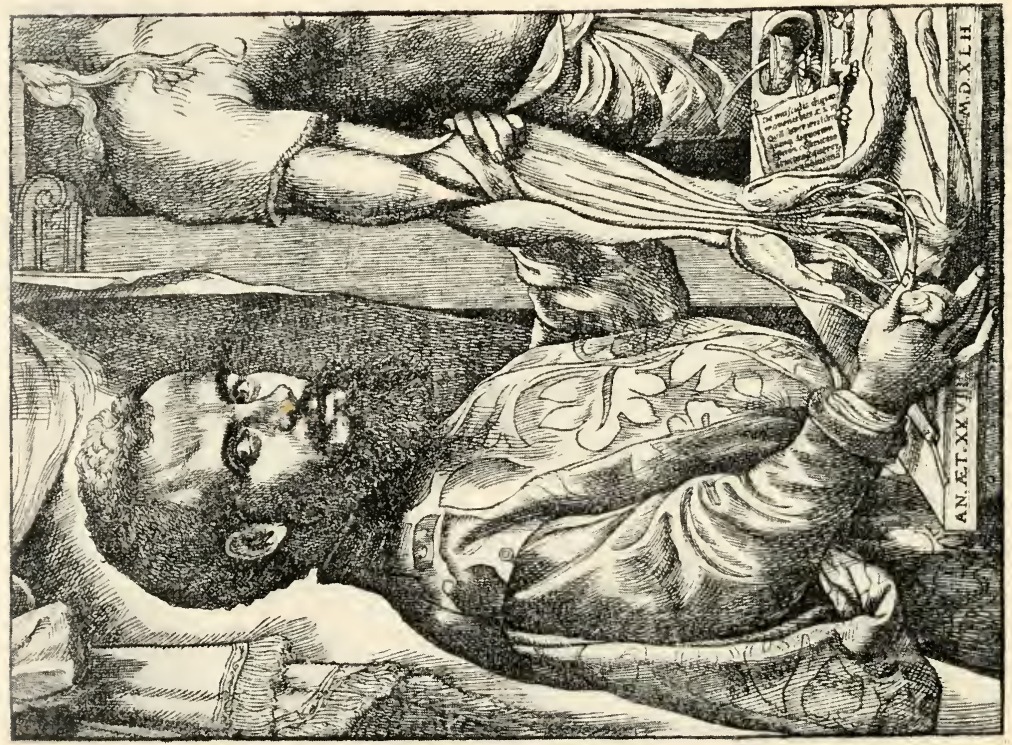

ते

D 


\section{VESALIUS AND THE NEW ANATOMY}

A MORE important writer than Berengar and one of the greatest scientific investigators that has ever lived was the Belgian, Andreas Vesalius, who was beginning his work about the date of Berengar's death. Vesalius was born at Brussels on the last hour of the last day of the year I5I4. Even as a boy he showed very great interest in science. He was always observing nature and constantly dissecting the bodies of any animals that he could get. A taste for natural history is common enough among boys and girls nowadays, but it was much rarer then. Nowadays nature study is taught in many schools, and it is easy to get books to help one. In his day men were but just emerging from the Middle Ages, when the study of nature was little thought of and no such books had yet been written. Vesalius had therefore to find his own way. For such a boy there was then only one profession possible, that of medicine.

Vesalius therefore became a medical student, and he studied first at the University of Louvain and afterwards at Paris. We have already seen how anatomy was taught in mediæval times, and the methods of instruction at Louvain and Paris had not improved much, if at all, on those of the Middle Ages. Vesalius soon got tired of hearing long passages of Galen read out by the professor. He therefore determined to go to northern Italy, where the newer and more scientific methods were being 
practised. Padua was the university of his choice. He immediately made his mark there, and was appointed a professor when only twenty-four years of age. He established a scientific tradition at Padua which that university has retained to this day.

It may seem surprising that a Belgian should be appointed to teach in an Italian university. You must, however, remember that at that time there was only one language for learning-Latin. All learned books, all medical books, nearly all religious books, all books on history and biography, and even most school text-books, in fact all serious books of any kind were at that time written in Latin. The lectures in the universities and even most of the lessons in the schools were given in Latin. The native language of a professor was therefore not of great importance. The really important thing was that he should be able to speak and write Latin fluently. This was, therefore, an essential accomplishment of every educated man, and one which Vesalius had early acquired.

No sooner was Vesalius settled as a professor at Padua than he applied himself with extraordinary diligence to lecturing and to research. He was a most successful teacher, and students crowded to hear him. His audience is said to have frequently numbered as many as five hundred. As an aid to his pupils he issued, in 1538 , soon after his appointment, a sort of students' guide to anatomy and physiology. It consisted of six fine plates of pictures with very full descriptions. These pictures show that he had made a careful examination of the human skeleton, but that his physiological views were still taken from Galen and Aristotle. In these plates he still speaks, for instance, of the liver as the source of the veins, and the heart as the source of the arteries and of the innate heat. 
During the four years that followed the issue of this guide he had ample opportunities to dissect. He spent all the time he could spare from teaching in the preparation of his great work on anatomy and physiology. It was printed in 1543 in a magnificent and beautifully illustrated large folio volume under the title The Fabric of the Human Body. This work is one of the landmarks in the history of science. The Fabric of the Human Body is the first great work of anatomy or physiology since the time of Galen. It is, for its time, a wonderfully full record of a prodigious number of accurately recorded discoveries and investigations made by a single observer.

After the issue of his students' guide of 1538 , Vesalius had found that Galen and Aristotle were by no means always to be trusted. This discovery led him to doubt constantly any statement of Galen or Aristotle. His scepticism was sometimes excessive, for Galen and Aristotle were excellent observers. These doubts, however, led Vesalius to put every statement made by his predecessors to the actual test of experience, and this gave his work an epoch-making value.

When Vesalius came to investigate the heart he was in a peculiar difficulty. All the physiology of his time was based on the view of Galen, which necessitated a belief in the passage of blood from the right ventricle to the left through the pores of the septum and a belief that air entered the heart through the venal artery (our pulmonary vein). To cast doubts on this without explaining the action of the heart would be to upset the whole of the current notions of the workings of the human body without putting anything in its place. This Vesalius hesitated to do, and, although he hinted in his book that the passages through the septum have no real existence, yet he did not at first say so outright. 
The work of Vesalius on The Fabric of the Human Body was very well received by the scientific world. It immediately became the recognised text-book. Like all such works, it was inevitably given the most sincere form of flattery-it was copied by inferior writers, who often treated the discoveries of Vesalius as though they were their own. It is very remarkable that in spite of this flattering reception Vesalius was by no means satisfied with his position as a professor. It is believed that he was unduly sensitive to the criticism that was not unnaturally made of a work which had caused such a big stir in the scientific world. Perhaps, too, he felt unable to continue his work longer without expressing more clearly his disagreement with current views. Yet he really had no physiological theories to offer in place of those of Galen, and to destroy Galen's views without having anything to put in their place would be simply to introduce confusion. Perhaps, too, he feared the criticism of the theologians. Galen and Aristotle had been so long looked on as infallible that their views had become interwoven with the religious opinions of the age, which was a very intolerant one. These views, Vesalius well knew, it would be dangerous to disturb.

Whatever the reasons may have been, soon after the publication of his great work Vesalius took an extreme step. He resigned his professorship, burnt his notes and papers, and took up the post that was offered him as physician to the Emperor Charles v., the greatest monarch of the age. Vesalius was then only twenty-nine years old, but his scientific career was closed. Nevertheless, his book had sold so well that the edition was soon exhausted. The demand for more copies could only be met by imitations of his work by other hands. At last in 1555 , twelve years after the appearance of the first edition, he was prevailed on to issue a second. 
Vesalius, fully occupied as court physician, was no longer in a position to make new physiological or anatomical observations. The second edition of the work, though distinctly an improvement on the first, does not therefore exhibit many facts that he had not already recorded. It does, however, contain certain changes in point of view that were very important for the subsequent development of physiology. In the second edition of his great book Vesalius no longer merely hints his doubts as to the character of Galen's physiology, he openly asserts that he is unable to verify its fundamental bases. He was now in a strong position as the personal attendant of a powerful and orthodox monarch. He could therefore say what he meant with comparatively little fear or risk.

We may take a single instance of this new outspokenness. In his description of the septum of the heart he had written in the first edition: "The septum of the ventricles is formed from the very densest substance of the heart. It abounds on both sides with pits imprinted on it, by reason of which it is provided with an uneven surface towards the ventricles. Of these pits none, so far as the senses can perceive, penetrate from the right to the left ventricle. We are thus forced to wonder at the art (industria) of the Creator by which the blood passes from right to left ventricle through pores which elude the sight." This passage is altered to something quite different in the second edition, where he writes: "Although sometimes these pits are conspicuous, yet none, so far as the senses can perceive, passes from the right to the left ventricle. . . I have not come across even the most hidden channels by which the septum of the ventricles is pierced. Yet such channels are described by teachers of anatomy who have absolutely decided that blood is taken from the right to the left ventricle. I, 
however, am in great doubt as to the office of the heart in this part."

He further sets forth his whole policy with reference to Galen's view in the following interesting passage: "In considering the structure of the heart and the use of its parts, I have brought my words for the most part into agreement with the teachings of Galen: not because I thought that these were on every point in harmony with the truth, but because, in referring now and again to a new use and purpose for the parts, I still distrust myself. Not long ago I would not have dared to turn aside even a nail's breadth from the opinion of Galen, the prince of physicians. . . B But the septum of the heart is as thick, dense, and compact as the rest of the heart. I do not, therefore, know ... in what way even the smallest particle can be transferred from the right to the left ventricle through the substance of that septum.... When these and other facts are considered, many points concerning the arteries come forward about which doubts may reasonably arise. We may note too that almost no vein goes to ventricle, intestines, or spleen without an accompanying artery, and likewise the portal vein has an accompanying artery almost throughout its course." 


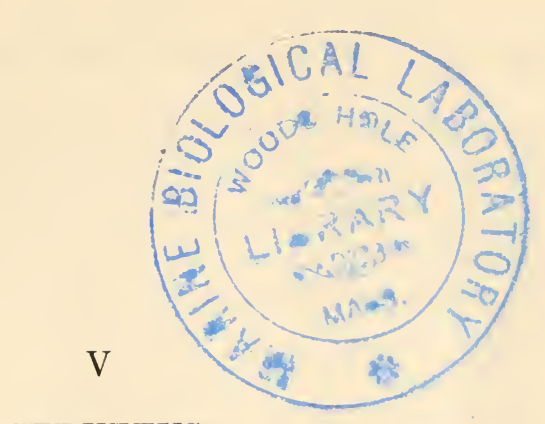

\section{SERVETUS}

THE next contribution to our knowledge of the circulation comes from a most unexpected source. It is not found in a scientific work but in a book on Theology. The recurrence of the discussion in such a place suggests how wide was the interest taken in the problem. The author of this work was Michael Servetus. As his career was one of the most remarkable and tragic in the whole history of science, we shall say a few words about him.

Michael Servetus was born in $\mathrm{r}_{5} \mathrm{II}$ at Tudela. That town is situated in Navarre, a district in the north of Spain, close to the French frontier. Servetus was educated mainly in France,--first at Toulouse, where he studied theology, and then at Paris, where he studied medicine and law. It is interesting to learn that he had there the same teachers as Vesalius. It is even possible that the two were actually fellow-students.

After Servetus left Paris he led a somewhat wandering life. At this time religious feeling ran very high in France, and indeed throughout Europe. The religious movement known as the Reformation was very recent and was still in progress. There was much bitterness between Catholics and Protestants, and neither party was willing to spare the other or to have mercy on any within their own body who was suspected of heretical views. Servetus was an inveterate theological disputant, and he wrote books that were most unwelcome to both parties. 
It is unnecessary for us to deal with his theological views, but we may say that they approached the standpoint nowadays called Unitarian. What concerns us is that in one of his books, written in Latin, with the title The Restitution of Christianity, he shows that he had attained to a clear view of the nature of the lesser circulation.

It may be asked why Servetus, a theologian before all things, took so much interest in physiology. The question is not difficult to answer. He had a belief that the study of physiology was one of the paths which lead to a knowledge of God. To know the spirit of God he considered that it was necessary to comprehend the spirit of man, and to know the spirit of man he thought it was necessary to attain to a right understanding of the structure and workings of the body in which that spirit dwells. On this account he introduced physiological discussion into his theological works.

If one glances at the theological writings of Servetus,and there are few who now do this,- - one sees at once that he is an obstinate and persistent advocate of the absolutely literal interpretation of Scripture. He accuses the world in general, and the Protestant theologian Calvin in particular, of not understanding Biblical phraseology. $\mathrm{He}$ piles up a host of quotations to show that he alone understands it. To give an example which bears on our subject. The Bible in several places closely associates blood with life. This idea is perfectly natural. It was by no means confined to the Bible, but was widely held in antiquity. Servetus, however, seizes on several Biblical passages which bring out this association. Thus in Genesis, chap. ix. ver. 4 , we read of " the life which is the blood " $;{ }^{1}$ in Leviticus, chap. xvii. ver. I I, we read " the life of the flesh is in the blood"; and in Deuteronomy, chap. xii. ver. 23,

${ }^{1}$ In the Latin "Vulgate " version in current use among Catholics this passage is rendered differently. 
" the blood is the life." In the Latin translation of the Bible which Servetus used, the word life is represented by the word anima, which may be translated spirit. These passages all have their special contexts, which do not concern us here. Nor did the contexts concern Servetus, who was all for the most literal interpretation. "The blood is the spirit," we can imagine Servetus saying, "and if we would know how the spirit is formed we must learn how the blood is formed, and if we would know how the blood is formed we must know how it moves." This is a point he discusses in the Restitution of Christianity.

In his purely physiological ideas, as expressed in the Restitution of Christianity, Servetus is still mainly under the influence of Galen and Aristotle, though he allows himself certain minor departures from their views. For the most part, however, he is merely repeating their phrases with his own theological tinge added. "There are said to be in us," he tells us, " three kinds of spiritsnatural spirits, vital spirits, and animal spirits-but there are, in fact, not three but only two kinds of spirits, for the vital spirits are passed on from the arteries to the veins, where they are called natural spirits. Thus first we have the blood, the site of which is the liver and veins. Then we have the vital spirits, the site of which is the heart and arteries. Thirdly, we have the animal spirits, the site of which is the brain and the nerves. In all three we see the workings of the spirit of the one living God. . . . It was into the heart of Adam that God first breathed the spirit [Genesis, chap. ii. ver. 7], and it was afterwards that it passed to his liver. By inspiration through mouth and nose, spirit is taken in, and that which is inhaled goes to the heart. The heart is the first part to live, and it is the central source of bodily heat. . . . But the material in which the spirit is carried is the blood, 
which is derived from the liver. Hence the spirit is said to be in the blood, or to be blood. The spirit is not said to be in the chambers of the heart, nor yet in the mass of the brain or liver, but in the blood itself, as God Himself teaches in Genesis, chap. ix. [ver. 4]; Leviticus, chap. xvii. [ver. I I] ; and Deuteronomy, chap. xii. [ver. 23]."

In all this there are only the doctrines of Galen and Aristotle slightly altered by the theology of Servetus and especially by his reading of the Bible. The one real change that he has made is to do away with the natural spirits, the product of the liver. He therefore admits only one kind of spirits in the blood, whether arterial or venous. This idea, it may be thought, would make it necessary for him to emphasise the communications between veins and arteries, because the vital spirit that is formed in the heart, and especially in the left ventricle, cannot get into the veins without such communication.

Now there is a passage in the writings of Galen in which he speaks of anastomosis between the arteries and veins. In older Greek the word anastomosis meant the act of making a mouth or hole. In later writings, however, the word came to mean something rather different. It might be used for two structures that are closely intertwined or connected with each other as are the veins and arteries, and Galen sometimes uses the word in this latter sense. In the passage in question, however, he has certainly the original meaning, ${ }^{1}$ and really seems to imply that there are certain openings between the arteries and the veins. He does not, however, attach importance to these openings. They are not necessary for his physiological system. Galen's actual phrase is " throughout the body the arteries anastomose with the

${ }^{1}$ De usu partium, vi. $\S$ Io. The actual word he uses here is

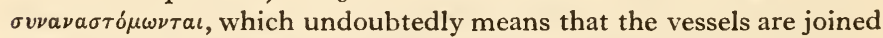
together by a mouth. A similar statement is made in vi. $\$ 17$. 
veins. They thus mutually give to each other blood and spirit through certain invisible and extremely narrow passages." The sentence presumably means that these fine passages unite artery and vein in the lung no less than in other parts of the body.

There is, however, in Galen nothing about circulation, the essence of which is movement always in the same direction. On the contrary, Galen emphasises the mutual character of the exchange and of the movement. Servetus, however, seizes on the passage and boldly declares that "the vital spirit passes from the arteries to the veins through the anastomoses." It is a very interesting illustration of how small a thing, a hint, an exceptional use of a word, a strained analogy, may lead to a great discovery. It is also a remarkable illustration of how near a great discovery a man may be without making it. Servetus was on the very brink of such a discovery; indeed, he actually enunciates it, as we shall immediately see. But he passes it by, deaf and blind to everything save the course of his own theological argument. The one passage, the one idea, in his book that time has shown to have been really original and important he introduces as an incident in the course of his argument.

$\mathrm{He}$ tells us that he considers that blood and life or spirit are the same in the sense that the one contains or includes the other. He then explains that to understand this we must learn how the spirit is generated and produced in the blood. In the course of explaining the process, he gives a perfectly clear exposition of the lesser circulation. He no longer attributes the generation of spirit entirely to the heart, but rather to the lungs. "The vital spirit," he says, " is generated through the mingling in the lungs of the inspired air with the subtle blood which is communicated to it from the right ventricle to the left. This communication does not, however, 
take place, as is generally believed, through the septum of the heart, but by a remarkable device the subtle blood is driven from the right ventricle through a long passage in the lungs. It is prepared by the lungs, and is there rendered lighter in colour, and from the artery-like vein [pulmonary artery] it is poured into the vein-like artery [pulmonary vein]. Then in the vein-like artery [pulmonary vein] it is mixed with the inspired air, and by expiration is cleansed from its fumes. So at length completely mingled [with the air] it is drawn in by the left ventricle during its expansion, ready to become vital spirit." Would it be possible to describe the pulmonary circulation better in so few words?

" That the communication and preparation," he adds, " does take place in this way through the lungs [and not through the septum] is moreover shown by the manifold conjunction and communication of the arterial vein [pulmonary artery] with the venal artery [pulmonary vein] in the substance of the lung. This is confirmed by the remarkable size of the venal artery [pulmonary vein], which would not have been made so large and would not discharge from the heart itself such a mass of pure blood into the lungs merely for nourishment." This is the first clear account of the lesser circulation. But can we call it a real discovery? Hardly. Servetus was so near and yet so far from being a great physiologist! But he tells us something of the physiological questions of his day, and he shows us how the world was, as it were, almost consciously awaiting a solution of the ancient problem.

Let us follow a little further the career of the man who wrote this. After he left Paris, Servetus spent a good deal of his time in practice as a physician at Vienne in south-eastern France. In I 546, the year of the completion of his work on the Resitution of Christianity, he opened 
a fatal correspondence with the theologian Calvin. Calvin lived at Geneva, then a small Protestant republic of which he was well-nigh dictator. Servetus sent Calvin, along with a letter on some theological topic, a manuscript copy of his book. Calvin was greatly incensed at the heretical character of the book and refused to return it.

Even at this time Servetus knew his life was threatened, for he wrote to a friend not long after, "I know of a truth that this work will be my death." He brooded long on it. The book was recast, but not finally issued until early in 1553 . It therefore appeared before the second edition of the great work of Vesalius. Its heretical character was but too obvious. Although the book was published anonymously, Servetus was suspected of being its author and was arrested. $\mathrm{He}$ escaped and reached Geneva, but was recognised and again arrested. He was tried and burned alive at Geneva on 27th October I553. So died one of the most remarkable figures in the annals of science. Calvin cannot be exonerated from his share in this cruel and wicked act, though it is said in his defence -if such it can be called-that he would have had him beheaded rather than burned!

When Servetus was burned, the edition of his book was burned with him. Copies of it are therefore excessively rare, and indeed only three are known to exist. To one of them now in the National Library at Paris a romantic and melancholy interest is attached. This copy was once owned by the prosecutor of Servetus at the Genevan trial. As he worked up his case against his unfortunate victim, he marked the passages that he thought the most damning, and his underlines can still be traced in the volume. The relic has yet another interest. It bears the marks of fire! Perhaps it was flung into the flames 
along with its author, but, more fortunate than he, was rescued by some kindly hand !

While Servetus was tried and burned at Protestant Geneva, the Catholic authorities at Vienne had not been idle. They, too, had tried him in his absence; they, too, had sentenced him to be burned alive. The sentence was confirmed by the Catholic ecclesiastical tribunal at Vienne after his death. It could hardly then be executed! $\mathrm{He}$ was, however, burnt in effigy, and honour was satisfied. 


\section{I \\ THE SUCCESSORS OF VESALIUS}

WHEN Servetus died, his work, as we have seen, was also burned, and it could not therefore exert a wide influence. A very few copies, however, survived, and it is probable that these were not without their effect. Moreover, he had been discussing the subject for years, and his opinions were, as we have seen, an open secret. Thus it has been thought that Servetus may have actually communicated his opinions to a certain colleague and successor of Vesalius at Padua, one Realdus Columbus. It is also possible that Columbus may have secured one of the few surviving copies of the Restitution of Christianity.

This Columbus was not a very original man, and published nothing on physiology during his lifetime. He had, however, written a text-book of anatomy, and this was printed by his children in 1559 after his death. The book is mainly based on Vesalius, whom he does not always understand, for he denies, for instance, that the heart is a muscle. The work of Columbus contains, however, an important contribution to our subjectindeed, it is the only important thing in it. The passage bears a close resemblance to that which we have quoted from Servetus, and runs as follows :

"Between the ventricles is the septum, through which almost all think there is a way from the right ventricle to the left, so that the blood in transit may be rendered subtle by the generation of the vital spirits in order that 
the passage may take place more easily. This, however, is an error; for the blood is carried by the arterial vein [pulmonary artery] to the lung. . . . It is brought back thence together with air by the venal artery [pulmonary vein] to the left ventricle of the heart. This fact no one has hitherto observed or recorded in writing; yet it may be most readily seen by any one. . . . Wherefore I cannot wonder enough that anatomists have not observed a matter so clear and of such importance. For them it suffices that Galen said so. There are some in our time who swear by the opinions of Galen and assert that he should be taken as gospel, and that there is nothing untrue in his writings." The passage seems to be a restatement of the views of his master, Vesalius, combined with those of the unfortunate Servetus. Nevertheless, it is important as the first widely distributed description of the lesser circulation. Similar views on the pulmonary circulation were expressed by several somewhat later writers of the sixteenth century. None of them, however, show any real advance on the position of Servetus and Columbus.

The next advance in the knowledge of the circulation was again made at Padua. It was in a sense the outcome of the teaching of Vesalius. The most promising of the pupils of Vesalius had been Gabriel Falloppius, a most gifted and versatile man. Falloppius made important contributions to anatomy and physiology, which, however, do not bear very closely on our subject. He occupied for some years the professorship at Padua that had been held by Vesalius. Falloppius was in turn succeeded by his own most promising pupil, Jerome Fabricius, who was therefore also in the direct Vesalian tradition-the grandson, so to speak, of Vesalius. The name Fabricius has been held by a number of men of science. This one, to distinguish him from his numerous namesakes, is 
usually called Fabricius of Aquapendente, after the small Tuscan village where he was born. Fabricius of Aquapendente taught anatomy at Padua for over fifty-four years, from 1555 till his death at eighty-two in I6r9.

Fabricius was a very learned man and an admirable observer. He made many most valuable contributions to the advancement of knowledge. Most of his works had physiological bearings. Thus he was the founder of modern embryology and the author of the first illustrated work on that subject, in which he describes the formation of the chick in the egg. He was the first to give accurate pictures of the structure of the eye. $\mathrm{He}$ developed the mechanics of muscular movement. Almost every department on which he touched he illumined by striking observations, and he added to his qualities as an observer those of a most attractive teacher.

In spite of all his powers, however, Fabricius lacked something which, if he had possessed it, would have placed him in the very front rank of men of science. For a man of his scientific abilities he was extraordinarily conservative. He never shook himself free from ancient views, and especially he was steeped in the theories of Aristotle and Galen. Aristotle was a very great naturalist, perhaps the greatest of all time, but like all men he made mistakes. Moreover, Aristotle had had few predecessors in the application of scientific method, and he had therefore less material on which to form his opinions than have modern writers. We must, therefore, judge him in relation to his own time and not to ours. But Fabricius, like many in his day, accepted fully the theories of Aristotle, though they were often founded on inadequate or even erroneous observations. This backward-looking habit of Fabricius prevented his work from being as interesting and as epoch-making as it might otherwise have been. In connection with the 
circulation, for instance, he made a most striking discovery, but wholly failed to draw out its most important lesson.

In 1574 he published his book On the Valves of the Veins. In it he says there are "thin little membranes on the inside of the veins distributed at intervals over the limbs. At times they are single, at times we find two of them together. Their mouths are directed towards the root of the veins [that is, towards the heart], and in the other direction [that is, away from the heart] they are closed." (Plate VII. Fig. 5.)

It is obvious to us now that these valves hinder the flow of blood except in the direction of the heart. Indeed, Fabricius shows this by an actual experiment that he describes and figures. He shows that if an arm be lightly bandaged so as to prevent the flow of blood back to the heart, the veins of the arm will swell up. This we now know is because blood can get into the veins of the arm from the capillaries but cannot get out towards the heart because of the bandage. In an arm so bandaged the valves will show up as nodes or swellings in the course of the veins. Fabricius actually draws attention to this fact. Yet all he has to say in explanation is : "In my opinion these valves are formed that they may to a certain extent delay the blood and so prevent the whole of it flowing to the feet, the hands, or the fingers and collecting there." He thus quite failed to recognise the true function of these valves. He was still thinking on the old Galenic lines of the ebb and flow of blood in the veins. He was still thinking that the use of the veins was to convey blood back and forth, carrying nutrient matter and natural spirits from the heart to the tissues and bringing back the impurities from the tissues.

The great contribution of Fabricius to the problems of the circulation was not so much his writing but his 
teaching. He was no great theorist but was a most stimulating teacher. Above all, he taught his pupils to observe with their own eyes. He would deserve our remembrance if only as the master of the effective discoverer of the circulation, William Harvey. It is of interest, therefore, to ascertain what Fabricius was actually saying about respiration, a subject so nearly bound up with the problem of the heart's actions. We may learn the views of Fabricius on this topic from his work On Respiration and its Mechanism, printed in 1603 . This book still contains the old Galenic physiological system almost unaltered.

In his summing up he tells us: "In respiration, Nature sets herself a double end, the generation of animal spirits and the regulation and maintenance of the innate heat. The heat is regulated by [a relation between] the fuel supplied, refrigeration [by the lung], and the elimination of the superfluities. All these are the result of the air taken into the body, whence the necessity for respiration. ... Respiration is the movement of air by which spirit is taken in and given out through the mouth. In inspiration air enters the lung and the heart, carrying material and coldness ; in expiration, on the other hand, the superfluous residues are evacuated." The innate heat of the heart was thus even more of a reality to Fabricius than to Galen, and he is back again on the Aristotelian view. Thus he says that "the heart burns as with a flame." $\mathrm{He}$ does not even accept the lesser circulation as demonstrated by Servetus and by Columbus, his predecessor as teacher at Padua. 


\section{I I}

\section{HARVEY}

WE have seen how nearly all of the early advances in physiology and anatomy were made at the University of - Padua. The medical school there was undoubtedly the best of the time. As the sixteenth century was closing, a young Cambridge graduate named William Harvey entered as a student at the University where Vesalius, Falloppius, Columbus, and Fabricius had taught and worked. This young man was destined to change all the current ideas of the working of the body, and to revolutionise the practice of medicine and of all the sciences connected with it.

William Harvey was born at Folkestone in 1578 , the eldest of the nine children of Alderman Thomas Harvey. He was educated at the King's School at Canterbury, and went to Gonville and Caius College, Cambridge, in I 593. That college had already a strong link with Padua. Gonville College, as it had been previously called, had been refounded in 1557 by Dr. John Caius, whose name is now attached to it. Caius had studied in Padua under Vesalius as far back as 1539 . Full of the stimulus of the great teacher, he had returned to England and lectured on anatomy in London from 1544 to $\mathbf{I}_{5} 64$. Caius was, moreover, one of the most prominent agents in this country of the revived knowledge of Greek. An enthusiast for the study, he had himself translated and edited several of Galen's anatomical works. The tradition of 


\section{PLATE V}

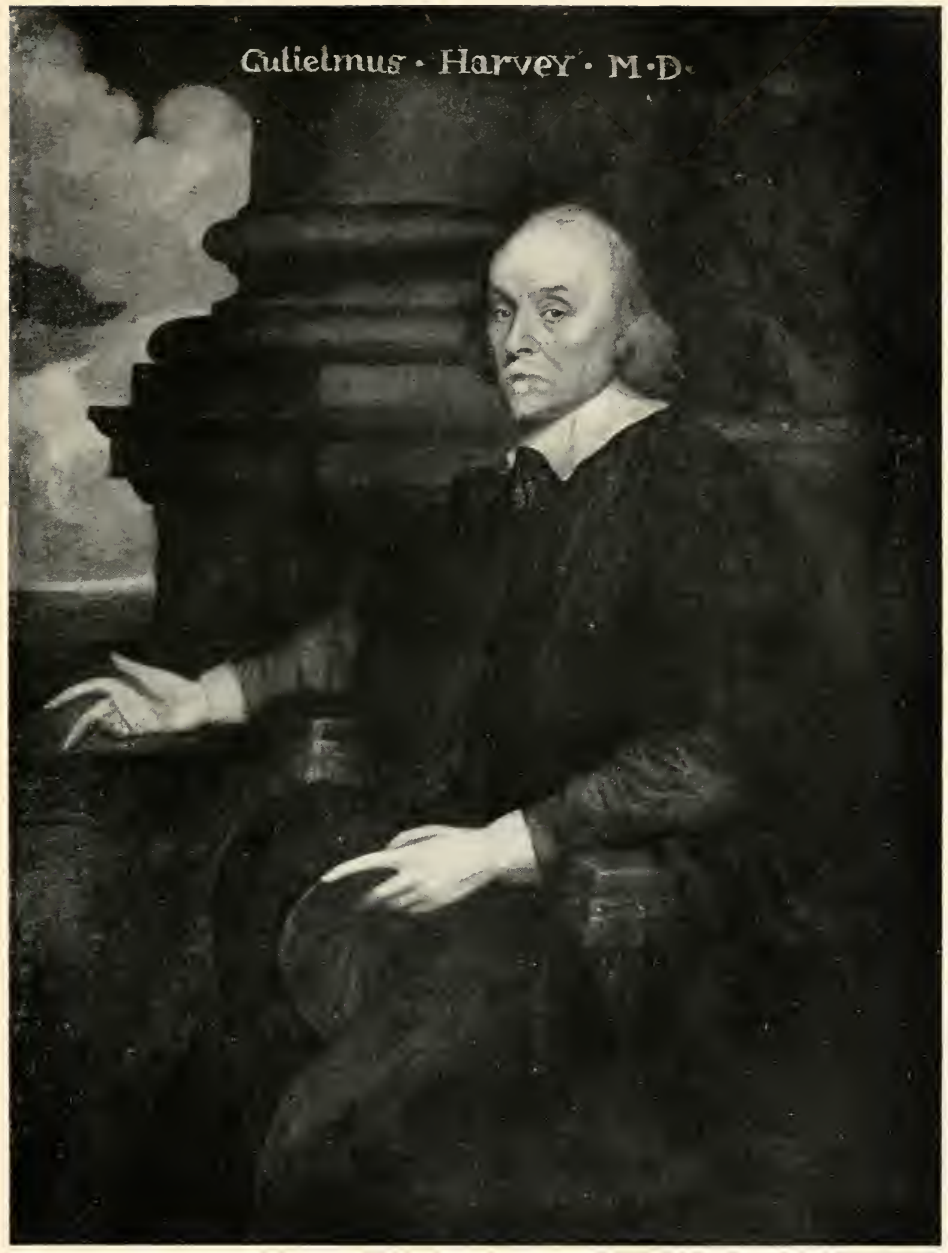

(By courtesy of Sir D'Arcy PoWEr.)

\section{William HaRvey.}

From the painting by CoRnelius JANSsen in the Royal College of Physicians, 


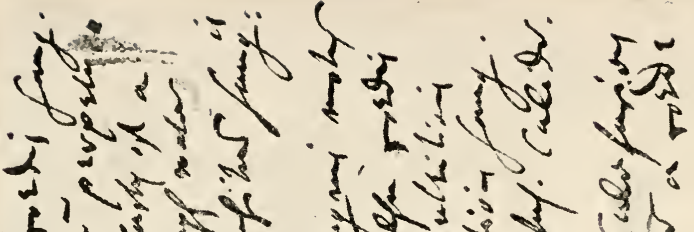

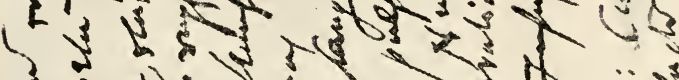

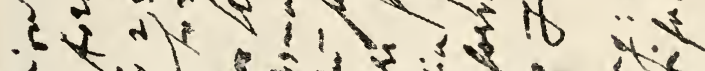

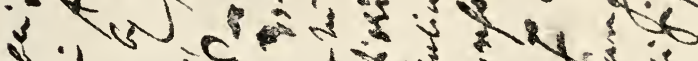
स. 5 की

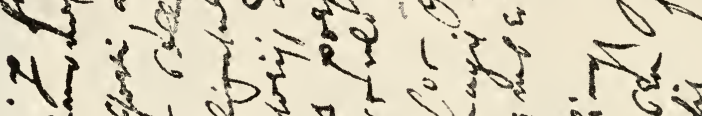

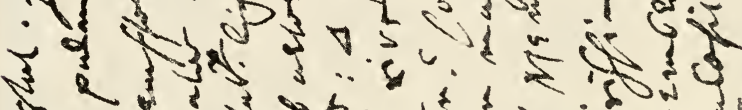

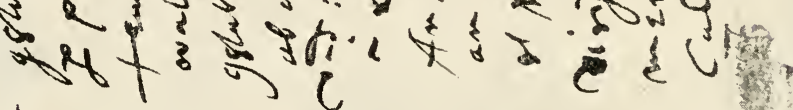
ts
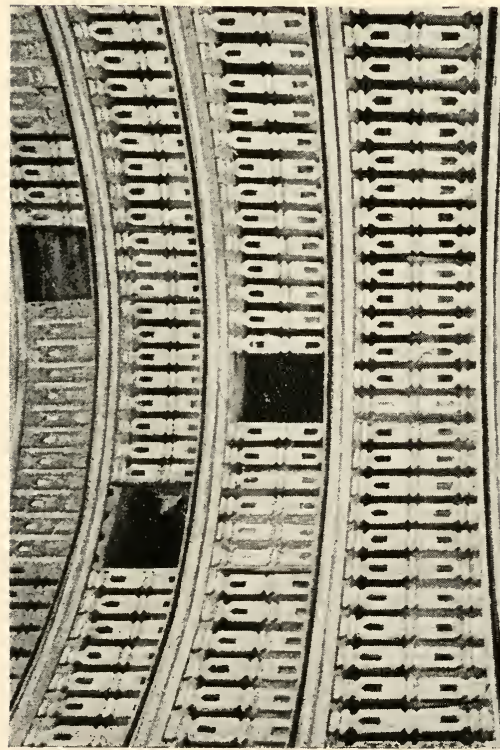

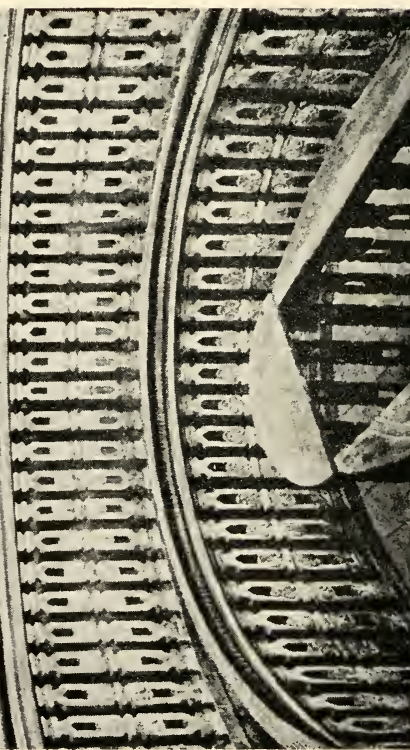


Greek learning and Italian anatomy that Caius had founded at Cambridge was strong in Harvey's time. It accounts for much of Harvey's attitude towards the ancient writers, and it may have been a factor in his selection of Padua as his school.

In 1597, then, Harvey, having taken his degree at Cambridge, went to Padua. Fabricius of Aquapendente was now at the very height of his powers and fame. Harvey became his pupil, and the greater pupil afterwards fully acknowledged his debt to his great teacher. At Padua there was a curious lecture room, lined with carved oak, where Fabricius used to give his lectures by candlelight. The old room is still standing (Plate VI.), and we can picture the eager young Harvey, with his great, wondering, thoughtful eyes, sitting there listening and eagerly drinking in the eloquent expositions of the greatest living exponent of physiological science.

While Harvey was at Padua, Fabricius was reading the proof-sheets of his work on the respiration, from which we have already quoted. That work, therefore, gives us a good general idea of the views that Harvey held when he embarked on the researches that led to his great discovery. In I 602 Harvey took the degree of M.D. at Padua and returned to England. The same year saw him capped as a Doctor of Medicine at Cambridge and settled down to medical practice in London. In I609 he was elected physician to St. Bartholomew's Hospital.

In 16I5 he was elected lecturer at the College of Physicians in London. His first course was delivered in the following year, and the manuscript notes he used are still in existence. The notes are in a curious mixture of English and Latin, and so badly written that they can hardly be read. They show, however, that he had already mastered the idea of the circular movement of the blood. Throughout these notes, as in his book which we shall 
immediately discuss, Harvey urges the illustration of the physiology and anatomy of man from that of animals.

In the section of the manuscript notebook that deals with the heart, Harvey describes its structure and that of the great vessels. Then he goes on to deal with the contraction of the various cavities of the heart and of the great vessels. He terminates this short section by saying that he has demonstrated the perpetual motion of the blood in a circle, and that this motion is produced by the heart-beat.

In these lectures, as in his other works, Harvey shows considerable but not remarkable learning. He pays very great, almost excessive, homage to the ancient writers. His respect for the ancients is perhaps somewhat unusual even for his time, an age that almost worshipped the past. Yet his acquaintance with Greek anatomical and physiological writings was evidently mainly, if not entirely, through Latin translations. From his frequent quotations we can make out a list of the books that he had read, and it is evident that his reading was typical of his age and of his own conservative leanings. What he omits is almost as characteristic of the man as is what he inserts. His lecture notes are full of homely references, yet he does not mention the works of Shakespeare, his contemporary, nor any of the literature of his time. The authors he quotes most frequently are, first, Aristotle and then Galen. He was very closely acquainted with the works of the greatest anatomical writers of his age, Vesalius, Falloppius, Columbus among them, and, especially and naturally, those of his teacher, Fabricius.

The chief characteristic that separates these lecture notes from most of the anatomical works of his time, except those of Fabricius, is the remarkably extensive first-hand knowledge of the anatomy of animals they exhibit. We have seen that Fabricius had set him the 
example in this matter, and the lesson had been well learnt. The lecture notes show that by 1616 Harvey had already dissected very carefully more than eighty different kinds of animals. This performance is the more remarkable when we remember that he had been in busy practice ever since settling in London.

There is one page of the lecture notes on which we may concentrate our attention (Plate VI.). It is only half-filled with writing, and the actual words on the page, copied line for line, are as follows :-

WHconstat per fabricam cordis sanguinem per pulmones in Aortam perpetuo transferri, as by two clacks of a water bellows to rayse water constat per ligaturam transitum fanguinis ab arterijs ad venas vnde $\Delta$ perpetuum sanguinis motum in circula fieri pulsu cordis An? hoc gratia Nutritionis an magis Conservationis sanguinis et Membrorum per Infusionem calidam vicissimque sanguis Calefaciens membra frigifactum a Corde Calefit. $^{1}$

This, so far as it is translatable at all, may be translated as follows :-

"On account of the structure of the heart, William Harvey is of the opinion that the blood is constantly passed

1 The passage contains two peculiar signs which need explanation. At the beginning is the sign $\mathrm{WH}$, making an abbreviated form of the initials of William Harvey's name. He was accustomed to put this monogram opposite statements that he thought peculiarly his own. The other sign is the triangle $\Delta$ which is the capital form of the Greek letter delta. This sign Harvey uses as an abbreviation of the phrase "it is demonstrated." 
through the lungs into the aorta, as by two clacks of a water bellows to raise water. Moreover, on account of the action of a bandage on the vessels of the arm [see p. $5^{8}$ below] he is of the opinion that there is a transit of blood from the arteries to the veins. It is thus demonstrated that $a$ perpetual motion of the blood in a circle is brought about by the beat of the heart. What shall we say? Is this for the purpose of nutrition? Or is it for the better preservation of the blood and of the members by imparting heat to them, the blood by turns losing heat as it warms the members, and gaining heat from the heart ?"

The three sentences, "the blood is constantly passed through the lungs into the aorta as by two clacks of a water bellows to raise water," "there is a transit of blood from the arteries to the veins," and " a perpetual motion of the blood in a circle is brought about by the beat of the heart," conclusively prove that Harvey had already attained to an understanding of the essential points in the circulation of the blood.

One phrase requires a little further explanation. It is the curious expression in which the action of the heart in driving blood through the lungs is compared to " two clacks of a water bellows to raise water." A clack in the English of Harvey's day was a form of valve used on pumps or "water bellows." Such a valve or " clack" was opened by the upward movement of the water produced by suction, and closed again by the backward pressure of the weight of water. Thus a writer contemporary with Harvey tells us that " a clacke is a piece of Leather nayled ouer any hole hauing a peece of Lead to make it lie close, so that ayre or water in any vessell may thereby bee kept from going out." 1 The two

${ }^{1}$ John Bate, Mysteries and Arts in foure seuerall Parts, London, I635. The quotation we have given is from Part I. Of Water Works. 
clacks or valves to which Harvey refers are doubtless, first, the valves between the auricle and ventricle which prevent blood that has once entered the ventricle from getting back into the auricle, and second, the valve at the commencement of the pulmonary artery which prevents blood once driven into that vessel from the ventricle, from getting back again into the ventricle.

Harvey soon attained eminence in his profession. In I6r 8 he was appointed physician to King James I., and he must have been very busy about the Court. He cared little for politics, but took the Royalist side in the Civil War, served with Charles' army, and was present at the battle of Edge Hill. There are many indications to show that he was widely trusted by his medical colleagues as a wise and discreet adviser. He was not one of those unhappy geniuses of whom it is said that " a prophet hath no honour in his own country" (JoHN, chap. iv. ver. 44). In spite of his other occupations he continued to lecture regularly at the College of Physicians. Yet, strangely enough, these lectures, embodying the most revolutionary doctrine delivered by the most sober and conservative of lecturers, seem to have attracted little attention. Their full importance was certainly not appreciated for some years.

Soon, however, his views were to reach a wider audience. In 1628 there happened an event of primary importance for the progress of science. In that year Harvey published at Frankfurt his great work-a very great work it is in a wonderfully small bulk. It is a badly printed quarto volume of 72 pages, containing a very large number of misprints. These need not surprise us when we glance again at his handwriting! (Plate VI.). The book is in Latin and is called An Anatomical Dissertation concerning the Motion of the Heart and Blood in Animals. It is dedicated to King Charles I., who had ascended the 
throne three years previously, and this dedication is of some interest as showing the cast of Harvey's mind. He begins it by comparing the king in his kingdom with the heart in the midst of the body. The comparison is borrowed from Harvey's favourite author, Aristotle.

In the introduction which follows, Harvey sets forth the views that had been held as to the structure of the heart and the motion of the blood. These we have for the most part already discussed. Then follow seventeen chapters in which the subject is demonstrated. It is on these chapters that Harvey's title to fame is based. We shall attempt to epitomise them.

Harvey's book, though very convincing, is by no means easy reading. For this there are various reasons. Thus he frequently refers to ancient authorities, with whom the modern reader is unfamiliar. It was necessary for him to deal with these ancient authorities, because they provided the current views of the seventeenth century. To a reader nowadays, however, the constant return to the opinion of the ancients often forms an obstacle to the understanding of Harvey's argument. In Harvey's time, too, men were unaccustomed to the physiological method of research. He had therefore to devote much of his space to justifying deductions drawn from one creature being applied to another, matters that are now often mere physiological commonplaces. Again, the Latin style selected by Harvey is not well adapted to scientific discussion. The sentences are often exceedingly involved, and there are passages too that are by no means easy to understand or to render. The resulting translation is, therefore, bound to be somewhat quaint, and Harvey, we must remember, was conservative in reading and outlook even for his own time. Moreover, the actual division and arrangement of the subject- 
matter of the book are not altogether what they might be, and the division into chapters does not exactly correspond to the division of subjects. Add to all this that Harvey was evidently not a very careful or patient proof corrector, as is shown by the large number of printer's errors that he left in the text. Lastly, there are great practical reasons that make it a difficult book. One is that it is extremely condensed and contains a vast number of facts, conclusions, and observations in a very small space. Another is that it was the first time that anything of the sort had been attempted, and Harvey was grappling with a new idea. 


\section{I I I}

\section{AN EPITOME AND ESTIMATE OF HARVEY'S WORK}

\section{(a) The Preliminary Observations}

IN summarising this great work we shall try to avoid its difficulties. Sometimes we shall give Harvey's conclusions in our own words, sometimes in his. His antiquated references we shall mainly omit. At times we shall rearrange his subject. It will be best to classify his material into a series of sections, which do not always correspond to his chapters. Each of these sections leads to a conclusion, but they will differ greatly in length according to the amount of material to be considered or the difficulty of understanding the point with which each deals.

I. "If the heart is grasped in the hand, it may be felt to become harder during its action. This hardness proceeds from tension, just as when the forearm is grasped, its muscles are perceived to become tense and firm when [these muscles] move the fingers."

The contraction or systole of the heart therefore corresponds to its active position; its expansion or diastole corresponds to its position of rest.

2. "It may further be observed in fishes and coldblooded animals [in which the heart beats long after the death of the animal] ... that when the heart moves it becomes of a lighter colour, and when it is quiescent 
it becomes of a deeper blood-red colour. It thus seems evident that during action the heart ... becomes erect, hard, and of diminished size. The movement is plainly of the same nature as that of the muscles when they contract."

During contraction the heart diminishes in breadth and increases in length. Owing to this increase in length, the apex of the heart strikes the chest wall during contraction of the organ on the left side. It can be easily felt and seen to beat under the fifth rib. A new point has here been raised. It had naturally been believed that it was during expansion that the heart struck the chest wall. Harvey showed that it was during contraction that this event took place. The point raised by Harvey had been hinted at, however, by Leonardo, who had made experiments which, rightly interpreted, would have led to the same conclusion.

3. The contraction of the heart and the striking of the apex of the heart against the chest wall are also simultaneous, or almost simultaneous, with another phenomenon, namely, the expansion of the arteries, which may be felt as the pulse. The observation disposed of the view, that had been held by many, that the pulse was a result of the active expansion of the arteries or even of the substance of the blood itself, coincident with the expansion of the heart. Those who held this view thought that the expansion of the heart and the expansion of the arteries was part of one and the same event, an expansion extending right through the vascular system. Harvey's new observation made it highly probable that the contraction of the heart was the cause of the expansion of the artery, and therefore the cause of the pulse.

4. This third conclusion is confirmed by the character of the bleeding from an artery that has been cut. The 
blood gushes forth from a severed artery by spurts. These spurts take place at the moment when the ventricle contracts, not when it expands.

5. The auricles can be shown to have somewhat the same relation to the ventricles that the ventricles have to the arteries. In the dying heart of an animal, the ventricles cease beating before the auricles. If the tips of the ventricles are removed so as to expose their cavities, then each beat of the auricles will be seen to be followed by a corresponding spurt of blood from the opened cavity of the ventricles. In other words, at each beat or contraction of the auricle, blood is driven into the corresponding ventricle.

6 . In the intact heart the contraction of the auricles is followed by that of the ventricles. The same blood, therefore, that is driven into the ventricles by the contraction of the auricles is subsequently driven into the arteries by the contraction of the ventricles.

7. Once the blood has entered one of the great arteries - whether the aorta or the pulmonary artery-it cannot return along the path by which it came. Its movement in that direction is absolutely stopped by valves. This, as we have seen, had been successfully demonstrated by previous investigators and notably by Leonardo.

8. But Harvey introduces a new point in connection with the conclusion of paragraph 7 . He points out that this process must be continuous. This leads him to a very crucial discussion. Consider the capacity of the heart. Let us suppose the ventricle holds but 2 ounces of blood. The pulse beats 72 times a minute and $72 \times 60$ times an hour. In the course of one hour, therefore, the left ventricle will throw into the aorta or the right ventricle into the pulmonary artery no less than $72 \times 60 \times 2=8640$ ounces $=38$ stones $8 \mathrm{lb}$. In other words, in one hour the ventricle will throw inte the great artery more than three 
times the body weight of a heavy man. Where can all this blood come from? Where can it all go to? We know that the valves at the root of the great arteries prevent it regurgitating. It cannot come from the ingested food and drink, for no one could consume so much in one hour! It cannot go to and remain in the tissues, for they would soon all burst and ooze with blood!

9. But if all this blood is sent out by the arteries into the body, and if the body itself is not large enough to supply it, where does it come from ? It must come from the veins, which also contain blood. This conclusion is reinforced by a very simple piece of knowledge. The proportion of the weight of the blood to that of the rest of the body is known, and it is well known too that if an artery of any size is cut, and no remedies applied, we should bleed to death in a very short time. The bleeding would get slower and slower until it finally ceased as the blood was exhausted and death approached. The reason must be that the blood, being lost, does not reach the veins and so cannot return again from them to the arteries. Blood does not escape in the same rapid way from severed veins, because their walls are flabby and have little muscle or propelling power.

10. But how does this blood get from the venous system to the left side of the heart? And how, too, does it get from the arteries into the veins? These are the crucial questions in the whole discussion. We know the answers to them now. Let us see how Harvey sought to answer them.

Blood can enter the right auricle through the vena cava, the opening of which into the right auricle is patent and obvious. It can then enter the right ventricle, the opening into which from the right auricle is equally obvious, though guarded by valves. Regurgitation through this auriculo-ventricular orifice is prevented 
by these very valves. From the right ventricle there is, however, one exit, the pulmonary artery, or, as Harvey calls it, the arterial vein. If it enters that vessel it cannot regurgitate again, for " there are three sigmoid or semilunar valves at the orifice of the arterial vein [pulmonary artery], which completely prevent blood sent into the vessel from returning to the cavity of the heart."

The whole passage which follows is saturated with Galen, who had gained an idea of the action of these valves without being able to draw the conclusions that Harvey reached. "From Galen," says Harvey, "that divine man, that Father of Physicians, it clearly appears that blood passes through the lungs from the arterial vein [pulmonary artery] to the small branches of the venal artery [pulmonary vein]."

Now it may reasonably be doubted here whether Harvey has rightly interpreted Galen. In saying that in the works of Galen the matter clearly appears, he is certainly giving Galen something much more than his due. The passages in the works of Galen that refer to this matter are neither clear nor are they even consistent with each other. There is, however, one short paragraph in Galen's very voluminous works which may bear the interpretation that Harvey put on it. Whether Galen meant it as Harvey interprets it we need not discuss. The important thing, however, is that Harvey, with all his over-respect for Galen, has the instincts of a great investigator and interpreter, and can see the real truth through Galen's verbiage. It is one of the many cases in the history of science in which a truth half seen or but dimly seen, and therefore imperfectly and obscurely expressed by an earlier writer, awaited a later investigator to grasp its nature and importance and to express it adequately. To whom shall the honour be given? It is a question that can never be answered fully, because science 
is a continuous process, a growth, and can exist only as growth. It is often the mark of genius that the meaning of a phrase is fuller and deeper than even its author is aware. Each investigator, too, must of necessity build on the work of those who came before him, so that no discovery is in a strict sense entirely new. It is the demonstration of this process of growth or continuity, and the discovery of the deeper meanings underlying works of genius, that give its chief interest and charm to the history of science.

Harvey's respect for Galen is thus a form-perhaps some of his readers may think it becomes a rather tiresome form-of the humility and modesty that has characterised most great discoverers. He goes on attributing to Galen what is effectively his own discovery : "The heart then is continually receiving and expelling blood by and from its ventricle, and for this end is equipped with four sets of valves-two for the expulsion of blood and two for its admission. ... As then the blood is continually flowing into the right side of the heart and flowing out of the left side of the heart, it is obvious that it must somehow pass from the vena cava into the aorta... . It thus clearly appears that the blood must penetrate through the porosities of the lung from the right to the left ventricle [to get] from the vena cava to the aorta."

\section{(b) The Solution}

I I. Here the author pauses and makes some interesting reflections.

"What is now to be said on the quantity and source of the blood which thus passes, is so novel and unheardoff that I . . . tremble lest I have mankind at large for my opponents, so much doth wont and custom become a second nature. Doctrine, once sown, strikes its root 
deep, and respect for antiquity influences all men. . . . I had long considered what was the quantity of blood transmitted, and in how short a time its passage might be effected. I did not find it possible that it could be supplied by the juices of the ingested food . . . unless the blood should somehow find its way from the arteries into the veins, and so return to the right side of the heart."

"I now began to think whether there might not be A MOVEMENT, AS IT WERE, IN A CIRCLE, and this I afterwards found to be true. I saw that the blood, forced by the action of the left ventricle into the arteries, was distributed to the body at large, and its several parts. In the same manner it is sent through the lungs, impelled by the right ventricle into the arterial vein [pulmonary artery]."

It is very strange that in the midst of this, his great discovery, he should return again to the Aristotelian position. But so it is! He continues his reflections in words which might almost be quoted from Aristotle, or rather from a medixval interpretation of Aristotle. " The heart then is the beginning of life ; the Sun of the Microcosm [that is of the human body], even as the Sun may be called the heart of the world. It is the heart by whose virtue and pulse the blood is moved, perfected, and made nutrient, and preserved from corruption and coagulation. The heart is the Lar [that is, the god of the hearth] which, discharging its function, nourishes, cherishes, quickens the whole body. The heart is the foundation of life, the source of all action."

12. Here he comes now to a conclusion which is best stated in his own words:

"And now the cause is manifest, why in our dissections we usually find so large a quantity of blood in the veins, so little in the arteries; why there is much in the right ventricle, so little in the left, which probably led the ancients to believe that the arteries con- 
tained nothing but spirits during the life of an animal. ${ }^{1}$ The true cause of the difference is this, that there is no passage to the arteries, save through the lungs and heart. When an animal has ceased to breathe and the lungs to move, the blood in the arterial vein [pulmonary artery] is prevented from passing into the venal artery [pulmonary vein] and from thence into the left ventricle of the heart. ... But the heart not ceasing to act at the same precise moment as the lungs, but surviving them and continuing to pulsate for a time, the left ventricle and the arteries go on distributing their blood to the body at large and sending it into the veins ; receiving none from the lungs, however, they are soon exhausted, and left empty." 'This is the reason why after death the arteries are often empty and the veins full.

He terminates this matter by remarking: "We are now in a condition to suspect why no one has yet said anything to the purpose upon the anastomosis of veins and arteries, either whether or how it is effected or for what purpose. I now enter on an investigation of that subject."

(c) Some Crucial Experiments

I3. He proceeds to examine serpents, which have the advantage that the heart continues to pulsate long after the animal is dead. In serpents, too, the great bloodvessels are very conveniently arranged for observation. He remarks that when a serpent is laid open and the vena cava is seized with forceps and the course of the blood below the heart thus interrupted, the part that intervenes between the forceps and the heart almost immediately becomes empty. At the same time the

${ }^{1}$ The word artery is known in Greek in the form a $\rho$ тाpia, arteria, and, like the word aorta, is derived from dei $\epsilon \epsilon \iota \nu$, äeivein, to raise or lift up. Some of the Greeks themselves derived it from án $\eta$, aer, meaning air, and Harvey shared in their error. 
heart will become of a much paler colour than before, even when in its state of dilatation. It also becomes smaller, because it is no longer filled with blood which normally reaches it from the vena cava. At last it begins to beat more slowly, so that it seems as if it were about to die. If, however, the impediment to the flow of blood is removed, the colour and size of the heart are instantly restored.

"But if the artery instead of the vein is compressed, you will observe the part between the obstacle and the heart, and the heart itself, to become inordinately distended, to assume a deep purple or even livid colour. At length it is so much oppressed with blood that you will believe it about to be choked. When, however, the obstacle is removed, all things immediately return to their natural state in colour, size, and impulse."

14. "Now make an experiment on the arm of a man, using a bandage as employed in blood-letting. The best subject is a lean man who has large veins. . . . Let the bandage be tied round the arm and drawn as tightly as can be borne. It will first be perceived that beyond the bandage, neither in the wrist nor elsewhere, do the arteries pulsate. Immediately above the bandage, however, the artery rises higher at each expansion and throbs more violently ... as if it strove to break through the obstacle to its current. . . . The hand retains its natural colour and appearance, though in the course of time it begins to get somewhat colder."

"After the bandage has been kept thus for some time, loosen it a little. ... The whole hand and arm will now instantly become deeply coloured and distended, and the veins themselves tumid and knotted. After ten or twelve pulses the hand will be excessively distended, injected, gorged with blood. ..."

"Now apply the finger attentively over the artery 
which is pulsating near the bandage. At the moment of slackening the blood will be felt to glide underneath the finger. Moreover, he on whose arm the experiment is being made is distinctly conscious of a sensation of warmth as the bandage is slackened. He feels too something, namely, a stream of blood, suddenly making its way along the course of the vessels and diffusing itself through the hand, which at the same time begins to feel hot, and becomes distended."

"In connection with the tight bandage we noted that the artery was distended and pulsated above the bandage, but not below it. In the case of the moderately tight bandage, on the contrary, we find the veins below, never above, the bandage, swell, and become dilated, while the arteries [below it] shrink. . . ."

"The moderately tight bandage then renders the veins turgid and distended, and the hand full of blood. I ask, therefore, whence is this? Does the blood that accumulates below the bandage come through the veins, or through the arteries, or does it pass by certain hidden pores? Through the veins it cannot come. Still less can it come through any system of invisible pores. It must needs then arrive by the arteries, in conformity with all that has been already said. That it cannot flow in by the veins appears plain from the fact that the blood cannot be forced towards the heart unless the bandage be removed, and when this is done, suddenly all the veins collapse, and disgorge themselves of their contents into the superior parts, the hand at the same time resuming its natural pale colour. . . . Moreover, if a man has had his arm thus bound for some little time with a moderately tight bandage, so that it has not only got swollen and livid, but cold, and if the bandage then is loosened, he feels something cold make its way upwards along with the returning blood. . ..." 
"Further, when the bandage is relaxed from extreme tightness [to moderate tightness], we see the veins below the bandage instantly swell up and become gorged, while the arteries meantime continue unaffected, this is an obvious indication that the blood passes from the arteries into the veins, and not from the veins into the arteries."

"This shows that there must therefore be either an anastomosis of the two [kinds] of vessels, or passages in the flesh and solid parts that are permeable by the blood. It shows too that the veins themselves have frequent communications with one another, because they all become turgid together, with the moderately tight bandage ... and, moreover, if any single small vein be then pricked with a lancet, they all speedily shrink."

I5. "We have now spoken of the blood that passes through the heart and the lungs ... [ [and of the blood that passes] from the arteries into the veins in the peripheral parts and the body at large. We have yet to explain, however, in what manner the blood finds its way back to the heart from the extremities by the veins, and how and in what way these are the only vessels that convey the blood from the external to the central parts."

"The celebrated Hieronymus Fabricius of Aquapendente, a most skilful Anatomist, and venerable old man ... made representations of valves in the veins.... These are situated at different distances from each other, and diversely in different individuals ... and are directed upwards or towards the trunks of the veins. . . (Plate VII. Fig. 5.) If therefore anything attempted to pass from the trunks into the branches of the veins, or from the greater vessels into the less, they completely prevent it. . . ."

"The discoverer of these valves did not rightly understand their use, nor have others added anything to our knowledge. Their function is by no means explained when we are told that it is to hinder the blood, by its 
weight, from all flowing into inferior parts." They do not, in fact, always do this, "for the valves in the jugular veins [in the neck] hang downwards, and are so arranged that they prevent the blood from rising upwards; in a word, the valves do not invariably look upwards, but always towards the trunks of the veins, invariably towards the seat of the heart."

I6. Now comes the real explanation of the action of the valves of the veins, on which much of Harvey's theory turns. "These valves are solely lest the blood should pass from the greater into the lesser veins ... lest, instead of advancing from the extreme to the central parts of the body, the blood should rather proceed along the veins from the centre to the extremities."

"And this I have frequently experienced in dissections of the veins. If I attempted to pass a probe from the trunk of the veins into one of the smaller branches, I found it impossible to introduce it far by reason of the valves; whilst, on the contrary, it was easy to push it along in the opposite direction, from the branches towards the trunk."

"That all this may be made the more apparent, let an arm be tied up above the elbow at A, A (Plate VII. Fig. I). In the course of the veins, especially in labouring men and those whose veins are large, are certain knots or elevations as at B, C, D, E, and F, which will now be seen. These knots are not only at the places where the veins branch, as at $\mathrm{E}$ and $\mathrm{F}$, but also where they do not, as at C and D. These knots are formed by valves, which thus show themselves externally."

"If you now press blood from the space above one of the valves, as from $\mathrm{H}$ to $\mathrm{O}$ (Plate VII. Fig. 2), and keep the point of the finger upon the vein below, you will see no influx of blood from above. The portion of the vein between the point of the finger and the valve $\mathrm{O}$ will remain 
empty. Yet the vessel will continue sufficiently distended above that valve, as at $\mathrm{O}, \mathrm{G}$. . . . If you now apply a finger of the other hand upon the distended part of the vein above the valve $\mathrm{O}$ (Plate VII. Fig. 3), and press downwards, you will find that you cannot force the blood through or beyond the valve. . . . You will only see the portion of vein between the finger and the valve become more distended, while the portion of the vein below the valve (H, O, Plate VII. Fig. 3 ) still remains empty."

"It therefore appears that the function of the valves in the veins is the same as that of the three sigmoid valves at the commencement of the aorta and pulmonary artery, namely, to prevent all reflux of the blood that is passing through them."

"Further, the arm being bound at A, A as before, and the veins full and distended, compress a vein with one finger L (Fig. 4), at a point below a valve or knot. Then with another finger stroke the blood upwards beyond the next valve $N$. You will now perceive that this portion of the vein $\mathrm{L}, \mathrm{N}$ still continues empty. . . . But if the finger first applied (H, Fig. 2, L, Fig. 4) is removed, the vein is immediately filled from below, and the arm becomes again as at D, C (Fig. I)."

"That the blood in the veins therefore proceeds from more remote to less remote parts and towards the heart, moving always in the vessels in this, and not in the contrary direction, appears most plain ... for the veins are free and open conduits of the blood returning to the heart, and are yet effectually prevented from serving as its channels of distribution from the heart."

\section{(d) Summary and Conclusion}

I7. "Now I may give my view of the circulation of the blood and propose it for general adoption."

"All things, both argument and ocular demonstration, 
confirm that the blood passes through lungs and heart by the force of the ventricles, and is driven thence and sent forth to all parts of the body. There it makes its way into the veins and pores of the flesh. It flows by the veins everywhere from the circumference to the centre, from the lesser to the greater veins, and by them is discharged into the vena cava and finally into the right auricle of the heart. [The blood is sent] in such a quantity, in one direction, by the arteries, in the other direction by the veins, as cannot possibly be supplied by the ingested food. . . . It is therefore necessary to conclude that the blood in the animals is impelled in a circle, and is in a state of ceaseless movement ; that this is the act or function of the heart, which it performs by means of its pulse ; and that it is the sole and only end of the movement and pulse of the heart."

We have now come to an end of Harvey's discovery, and have let him tell of it, as far as possible, in his own words. We have seen how the power of words, words such as innate heat, spirits, and anastomosis, had their influence in helping or retarding the course of knowledge. Words at different ages have different meanings, and at any age the exact and precise meaning of a word is often difficult to define. Often, however, much hangs on the exact interpretation of a scientific term. Science is, of course, concerned with observations and with inferences from them, not with words about them. But our knowledge of observations and inferences can only be expressed in words. Scientific nomenclature, therefore, though of secondary importance, must not be despised. Harvey's discovery introduced a very striking change into physiological nomenclature, a change to which we have often referred in the pages of this work.

In the old physiology the arteries were considered as 
distributing spirit and a higher form of vital activity, while the veins distributed nourishment and the lowest forms of vital activity. The arteries arose from the heart, and the veins, it was thought, from the liver. The words artery and vein meant something different of old to what they mean to us. The two systems, arterial and venous, were recognised to be intimately connected. Both were linked with the heart, though the relation of the arteries was the closer. One branch of the venous system, however, opened into the right cavity of the heart. The vessel, therefore, that arose from that cavity and linked it with the lung was thus really a branch of the venous system, and was therefore a "vein." It had thick walls like an artery and was therefore called the arterial vein. It is the vessel we now call the pulmonary artery.

A companion to this vessel connected also the left cavity of the heart with the lung. As a derivative of the left side of the heart from which the aorta arose, it was regarded as an " artery." Its walls, however, were thin like a vein, and it was called, therefore, the venal artery. It is the vessel we now call the pulmonary vein.

A result of the discovery of Harvey was the introduction of a new nomenclature. For us who look at the circulation from his point of view, new names are needed. The arterial vein has become the pulmonary artery, and the venal artery has become the pulmonary vein. For us an artery is a vessel which takes blood from the heart and a vein is a vessel which takes blood to the heart. For the men of Harvey's day arteries were distinguished from veins by containing a different kind of blood. They had no idea of the constant and massive change of arterial into venous, and of venous into arterial blood. Our conception of the difference between artery and vein is controlled by our idea of the circulation introduced by Harvey. A new nomenclature was therefore needed 
or, at least, a new application of the old nomenclature. The test was specially applied in the case of the lesser circulation, when the old arterial vein became the new pulmonary artery, and the old venal artery became the new pulmonary vein.

It is a change that Harvey himself foresaw, for he asks : "Why does not the arterial vein pulsate seeing that it should be numbered among the arteries, and why does the venal artery have no pulse [though it is a vein] ? It is because the pulse is the impulse of arterial blood."

"Why do the arteries have coats so much thicker and stronger than those of the veins? Because they have to sustain the shock of the impelling heart and the blood that bursts forth therefrom."

"Why has the so-called arterial vein the structure of an artery, and the so-called venal artery the structure of a vein? Because in function and constitution and everything else the former is in fact an artery, and the latter is in fact a vein."

But almost in the last words in his book the great investigator returns again to Aristotle, with whom he started. The imposing Aristotelian scientific system was at that very moment tumbling about the ears of the philosophers, destroyed by Galileo. But Harvey ends as he began, relying on Aristotle for what, even in those days, was an antiquated and demonstrably false view of the heart and its place in the animal economy.

"Are we to agree the less with Aristotle," he asks, " in regard to the sovereignty of the heart? Or, on the other hand, are we to inquire whether it receives sense and motion from the brain, and blood from the liver? and whether it be the origin of the veins and of the blood? They who affirm these latter propositions against Aristotle, overlook, or do not rightly understand ... that the heart is the first part which exists, and that it contains within itself 
blood, life, sensation, motion, before either the brain or the liver were in being, or had appeared distinctly, or, at all events, before they could perform any function. The heart, ready furnished with its proper organs of motion, like a kind of internal creature, is of a date anterior to the body: first formed, nature willed that it should afterwards fashion, nourish, preserve, complete the entire animal, as its work and dwelling-place : the heart, like the prince in a kingdom, in whose hands lie the chief and highest authority, rules over all; it is the original and foundation from which all power is derived, on which all power depends in the animal body."

Human beings are queer and incomprehensible mixtures, and great scientific discoverers no less so than other men! Often accounts of great scientists are written as though they had no faults or failings. A wiser way is to remember that these exist, but to concentrate rather on the really important events in their lives, the thoughts and infiuences and teaching that led up to their great discoveries. This we have tried to do with Harvey and the Circulation of the Blood.

How slight a thing determines a discovery! An accident, a suggestion, an analogy, a phrase, a word, even a word misunderstood! Many have tried to set forth a complete method of research. One there was in England in Harvey's time who devoted a vast amount of energy and ability to the task. Francis Bacon, Lord Chancellor of England, made such an attempt. Harvey esteemed him and his method little. Of him he is reported to have said, "He writes philosophy like a Lord Chancellor." Bacon, who himself showed little skill in experiment and no aptness for discovery, yet drew up a complete scheme for the investigation of Nature! It is a scheme that has never been acted on. Such formulæ for the conduct of scientific research 
have, in fact, seldom or never been used by working scientists. For the truth is there is no one method of science : there are as many methods as there are men of science, though doubtless most of those working at any particular science have much in common. The task of the man of science is first to observe the appearances which Nature presents, then to ascertain what lies behind those appearances, and, lastly, to link together his conclusions and observations into general laws. How he does this is not a matter of much concern, so long as he does it. Nor need he, as a man of science, concern himself with the question of what are the ultimate truths behind all the appearances that Nature presents to us. He has but to express general laws according to the knowledge of his day, knowing full well that a day will almost certainly come when his general laws and the ideas on which they are based will have to be modified or replaced. What is a matter of concern, however, and what does vitally affect the course of science is not how his ideas come to him, but how he proves or verifies the statements that he makes. The vague analogies, the loosely put suggestions, the confused reasoning of a Servetus may have the same source as the finely worked out conclusions of a Harvey. The two men are poles asunder when it comes to verification. Servetus is content with a statement, the other passes cautiously from observation to inference, from inference to verification in an orderly and stately sequence.

We may note, too, the careful way in which Harvey limits his problem. He refuses to be drawn beyond his subject. He will deal only with the knowledge that he has, knowing full well that further work may throw new light on his investigations. He sets out to discover the mechanical explanation of the movement of the heart, and he accomplishes his task triumphantly. But he will not be led aside by those ancient wills-o'-the-wisp, the discussion of the nature 
of the spirits or of the innate heat. "Whether or not the heart," he says, " besides propelling the blood, giving it movement and distributing it to the body, adds anything else to it-heat, spirit, perfection-must be decided on other grounds. So much may suffice at this time, when it is shown that by the action of the heart the blood is transfused through the ventricles from the veins to the arteries, and distributed by them to all parts of the body."

A word may finally be added as to the reception of Harvey's theory. On the whole he was fortunate in meeting less opposition than most great innovators. In the early years after the publication of his work, he might reasonably have complained of neglect, but he met no very great or embittered criticism. In spite of the disbelief of several eminent physiologists his views gained ground, gradually and slowly it is true, but very surely and steadily. He lived to have the rare pleasure of seeing them generally accepted. 

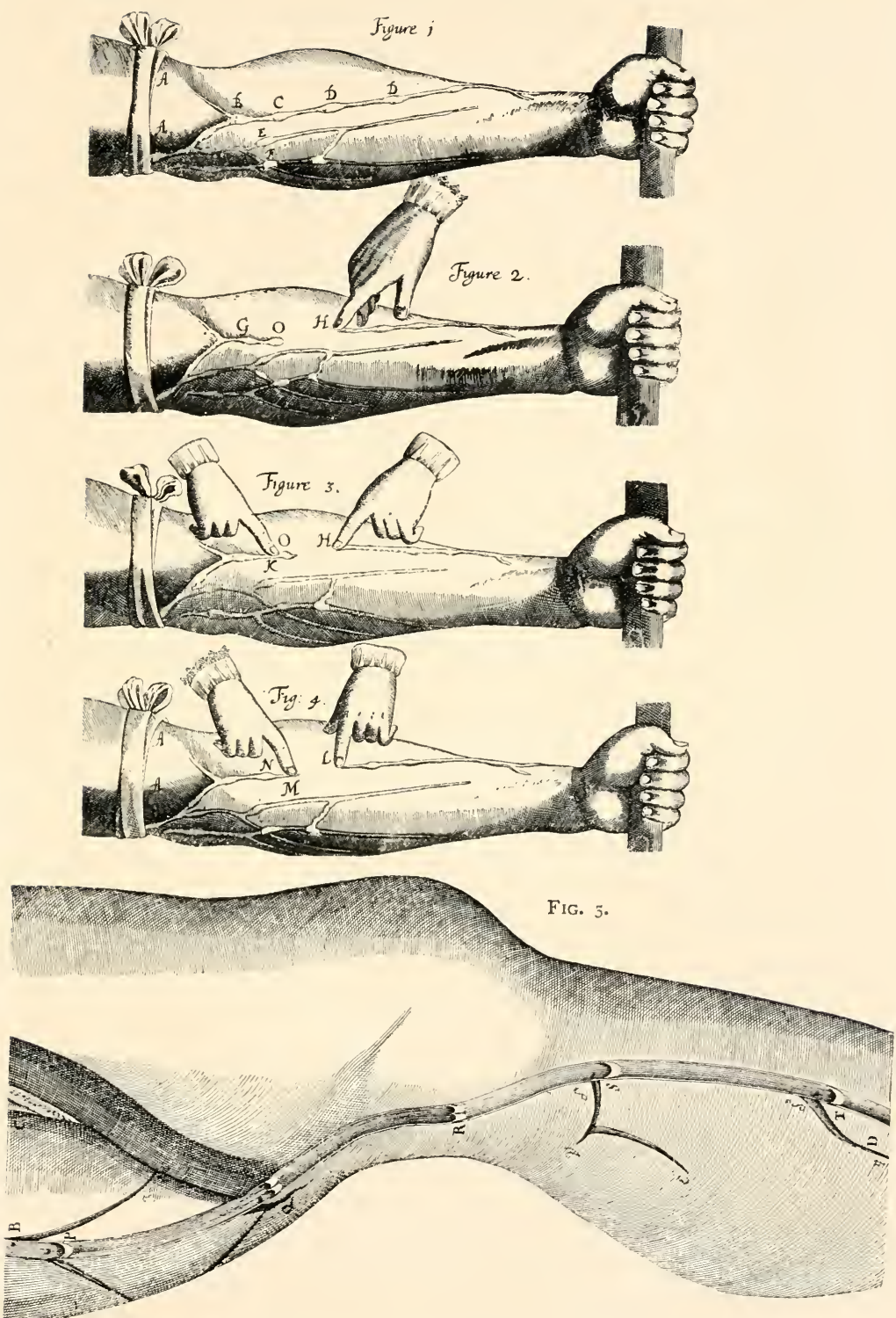

Figs. I-4. Experiments on Bandaged ArM. From Harvey.

Fig. 5. Dissection of Vein in Thigh and Leg to show Valves. From Fabricius, 
00
00
0

Fig.3.

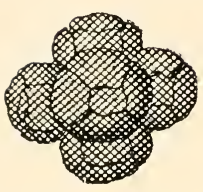

Fig.4.

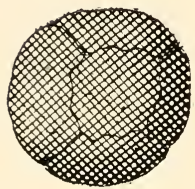

Fig.5.
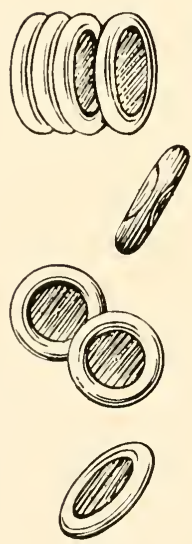

Fig.6.
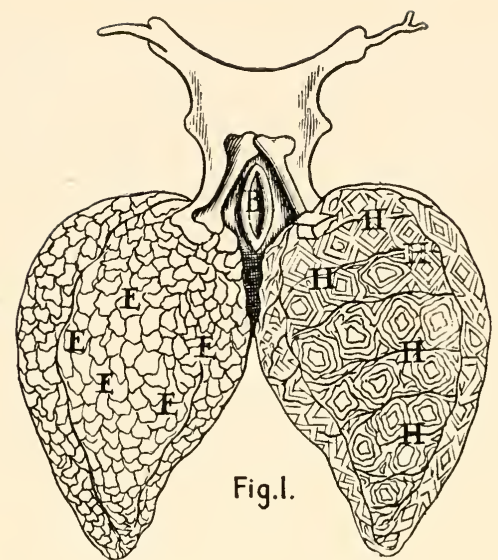

Fig.2.

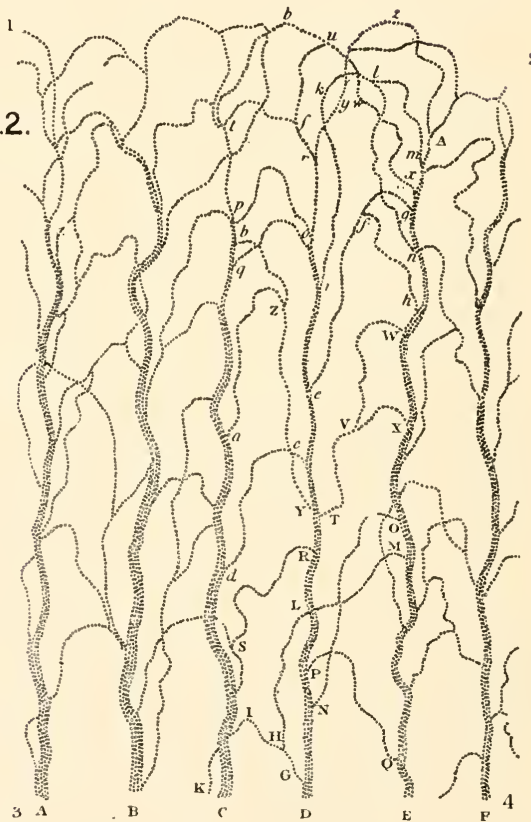

Fig. i. Lung of Frog, magnified, showing Capillaries. From Malpighi. Fig. 2. Capillary Network in Tail of Eel. From Leeuwenhoek. $\mathrm{A}, \mathrm{C}, \mathrm{E}$ are Veins, and $\mathrm{B}, \mathrm{D}, \mathrm{F}$ are Arteries.

Fig. 3. Red Blood Corpuscles of Salmon. From Leeunenhoek. Figs. 4 and 5. Human Red Blood Corpuscles. From Leeuwenhoek. Fig. 6. Human Red Blood Corpuscles drawn from the Object under a Modern Microscope. 


\section{THE DISCOVERY OF THE CAPILLARIES AND BLOOD CORPUSCLES}

HARVEY had demonstrated conclusively that the blood did circulate. There was one part of the circulation, however, that he left still a matter of inference. He had shown that the blood passed from arteries to veins, but he had not actually seen the passage. We now know that the stream goes through the capillary network. To see this, however, a microscope is necessary.

The microscope had been discovered in Harvey's time and long before the publication of his work on the circulation of the blood. Galileo had demonstrated its value as early as r6io. A few years later the instrument was brought to England. Nothing of real importance, however, was revealed by microscopic research until after Harvey's death in his eightieth year in 1657 . It is therefore not remarkable that he made no use of the instrument. A short time after his death his work was completed by the investigations of certain microscopic observers.

The compound microscope, as we have seen, was first made into an effective instrument by Galileo. It was, as it were, a by-product of his invention of the telescope. With his new instrument Galileo explored the heavens and made many new and important discoveries. He demonstrated the rings of the planet Saturn, he saw the satellites of Jupiter, and he examined the spots on the sun and the 
craters on the surface of the moon. Galileo saw enough with his telescopes to convince himself that the movement of the sun round the earth was but an appearance. At the very time that Harvey was giving his first course of lectures securely in London, Galileo's teaching was attracting the unwelcome attention of the Inquisition in Rome.

Galileo's microscopes, however, were far less satisfactory than his telescopes. For optical reasons, the nature of which we need not discuss, these early compound microscopes failed to give a clear picture. With any high degree of magnification the image was always blurred and distorted. The seventeenth century had more than passed its first half before a better device was introduced. But soon after 1650 a way was found of improving simple lenses of very high power. Even the improved high power simple lenses only gave a clear image of an exceedingly small area. Within that small area, however, the image was quite clear and was not much distorted. Many of the most important microscopical discoveries of the second half of the seventeenth century were therefore made with a simple lens. This was notably the case with much of the work of the great investigators, Marcello Malpighi, Jacob van Swammerdam, and Anthony van Leeuwenhoek, with whose work on the circulation we must now briefly deal.

Malpighi was born near Bologna in northern Italy in 1628, the year that Harvey's work was published. He went as a student of philosophy to the University of Bologna, but, having lost his parents, he changed his course for that of medicine. He very soon developed great ability in scientific research, and was especially skilled in minute investigation. He took a medical degree, and soon after, in 1656 , was elected professor of medicine at his own university. 
Malpighi had as yet written nothing, but his penetration and sagacity were early recognised by his colleagues. His singular beauty and simplicity of character were evident to all. His special skill in minute anatomy also soon drew attention. From an early date these qualities of his became known in England, and nearly all his works were published in London by and at the expense of our own Royal Society. The only one of Malpighi's publications with which we are here concerned, however, is his first. It was printed not in London but in Bologna, in 166r, under the title Anatomical Observations on the Lungs.

In this work Malpighi supplied the missing element in the investigations of Harvey. He was the first man who saw the actual passage of blood from arteries to veins. He saw the capillaries of the lesser or pulmonary circulation. The object which first yielded up the secret was the lung of the frog. This organ in the frog happens to be almost transparent. It is also very simple in structure, and is furnished on its surface with particularly conspicuous capillary vessels. Malpighi could hardly have selected a more suitable object for the purposes of this research. We may let him tell his own story.

He tells us that while to the naked eye " the frog's lung is nought but a membranous bladder ... to observation with the microscope it yields something much more remarkable." In the tiny vessels on the surface of the lung he could see that "the blood is forced and scattered by the pulse through the arteries into a network. . . As the blood stream, thus repeatedly divided up, is carried round in a sinuous manner, its colour fades. It is thus distributed until it approaches the walls . . receiving branches of the veins. . . While the heart is still beating, two movements in 
opposite directions can be seen, making the circulation of the blood quite evident. The same may be seen even better in the mesentery. ...."

"With unaided vision [and without the help of a microscope] I might have believed that the blood escaped into an empty space and was re-collected again by a gaping vessel, but for the tortuous and scattered movement of the blood in different directions and its union again into a definite vessel. . . . Such is the branching character of these vessels as they proceed on the one side from the artery and [are gathered] again on the other side to the vein ... that there appears to be a network made up of the continuations of the two vessels.... Hence it appears to the senses that the scattered blood flows along tortuous vessels, and is not poured out into spaces, but always continues in tubules, and that its dispersion is due to the multiple winding of the vessels" (Plate VIII. Fig. I).

A few years later Malpighi made a further important observation, the nature of which he failed to interpret adequately. Till his time and beyond, the colour of the blood was believed to be diffused through its substance. We now know that it is concentrated in the so-called red corpuscles, the minuteness of which gives the suspension-for such it is-the appearance of being a uniform red fluid. Malpighi caught a sight of these particles through his lenses, but he misinterpreted them. In examining a hedgehog he tells us that in a blood-vessel of the omentum "I saw globules of fat, of a definite outline and red colour. They were like a chaplet of red coral." These globules were the red corpuscles, and in the "chaplet" they were collecting together in rouleaux as they are very liable to do.

Similar observation of blood corpuscles had been made by several of Malpighi's contemporaries. Thus in 1658 
a German Jesuit named Kircher, in giving a very confused account of the plague, had described microscopic bodies in the blood of plague patients. He rushed to the conclusion that they were the cause of plague, but they were, in fact, rouleaux of blood corpuscles.

A better account was given by a Dutchman, Jacob van Swammerdam, at a date somewhat later than Malpighi's discovery. This Swammerdam was a most remarkable character, who in some respects resembled Servetus. Had he lived a century or so earlier he might have suffered the same fate. As it was, he passed his short life in comparative peace, though tortured by the misgivings of a diseased mind. His unstable and fanatical temper prevented him from publishing much work in his lifetime. $\mathrm{He}$ died in 1680 , and fifty years afterwards the manuscript of his great Bible of Nature was rescued and published. It is one of the most beautifully illustrated works on natural history that has ever been produced, and is a storehouse of valuable information, to which naturalists often turn even nowadays.

In that work Swammerdam wrote: "I saw a serum in the blood [of a frog] in which were a vast number of roundish particles, of a flat, oval, but regular form. . . . When I viewed them sideways they resembled crystalline clubs, or other figures, according as they were turned about in various directions in the serum of the blood. I observed besides that the colour of the objects always appeared the more faint the more they were magnified with a microscope." These were the red corpuscles. It should be added that Swammerdam says elsewhere that he thought he saw globules in the human blood, though he was inclined to think that they were formed after it had been removed from the body, and were not found in the blood while still confined in the vessels. 
The last writer whose work we have to consider is Anthony van Leeuwenhoek, another Dutchman, whose life covered nearly a century, for he lived from 1632 to 1723 . Leeuwenhoek was a man in a humble walk of life who never rose above the station of usher to a court in a small Dutch town. He owed nothing to any teacher or any university, and spoke and wrote no language but his own. In his youth there had been in Holland a widespread interest in Optics, and he developed remarkable skill as an amateur lens maker. His lenses got better and better, until finally he was making the best high power lenses in Europe.

At the same time Leeuwenhoek developed great talent as an observer and as a shrewd interpreter of what he observed. He did not publish anything until he was over forty. In 1674, however, a specimen of his work was sent to the Royal Society. The importance of it was at once perceived, and it was translated and appeared in the transactions of that learned body. From then on he corresponded regularly with the Society, who printed all or nearly all his work.

At first Leeuwenhoek did not believe in the circulation of the blood. He remained sceptical long after most better informed and better educated men had become convinced. He retained this attitude as late as I686, when, however, he began to waver. By 1688 he had completely changed his opinions, for, in that year, owing to the perfection that his microscopes had then reached, he clearly saw not only the systemic capillary circulation, but also the actual passage of the blood corpuscles through the minute capillaries. He described the capillary circulation in the web of the frog's foot, in the mesentery of the same animal, and in the tails of young fish (Plate VIII. Fig. 2). He described and 
figured clearly and accurately enough the blood corpuscles of frogs and other cold-blooded creatures (Plate VIII. Fig. 3), and also saw and figured-though rather less accurately-the blood corpuscles of man (Plate VIII. Figs. 4 and 5). The ocular demonstration of the circulation of the blood was thus at last complete. 



\section{B I B L I O G R A P H Y}

\section{GENERAL WORKS ON SCIENTIFIC METHOD.}

Norman Campbell, What is Science? (Methuen.) I92I, $5^{\mathrm{s}}$. Sir R. A. Gregory, Discovery, the Spirit and Service of Science. (Macmillan.) Tenth Edition, I92I, 7s. 6d.

Karl Pearson, The Grammar of Science. (A. \& C. Black.) Third Edition, I9I I, Ios.

F. W. Westaway, Scientific Method, its Philosophy and its Practice. (Blackie.) Second Edition, 1919, Ios. 6d.

\section{SPECIAL WORKS ON CIRCULATION OF THE BLOOD.}

\section{ANTIQUITY.}

Charles Singer, Greek Biology and Greek Medicine. (Clarendon Press.) 1922, 3s.

\section{LEONARDO AND THE RENAISSANCE.}

H. Hopstock in Charles Singer's Studies in the History and Method of Science. Vol. II. (Clarendon Press.) I92 I, 48s. Other material on this topic can be found in Vol. I. (now out of print) of the same work.

\section{VESALIUS AND HIS FOLLOWERS.}

Michael Foster, Lectures on the History of Physiology. (Cambridge University Press.) I901, 12s. 6d. 


\section{SERVETUS.}

The literature on Servetus is very scattered, but the article on him by the Rev. Alexander Gordon in the Eleventh Edition of the Encyclopadia Britannica is reliable.

\section{HARVEY.}

An Anatomical Disquisition on the Motion of the Heart and Blood in Animals, by William Harvey, translated from the Latin by RoBert Willis. (Dent, Everyman Library.) 2s.

J. G. CurTis, Harvey's Views on the Use of the Circulation of the Blood. (New York, Columbia University Press; London, Humphrey Milford.) 1915, 6s. 6d.

Portraits of Dr. William Harvey. (Milford.) I9I3, 21s.

\section{THE MICROSCOPISTS.}

L. C. Miall, The Early Naturalists, their Lives and Work, 1530-1780. (Macmillan.) I912, ros. 


\section{NDEX}

Alexandria, school of, ir.

Anastomosis between veins and arteries, 33,63 . meaning of the Greek word, 32.

Aortic valves, 6,8 .

Aristotle on heart, Io, I I. on innate heat, 16.

Arterial vein $=$ pulmonary artery, $6,13,38,54,64$.

Arteries, distinction from veins, 3,65 .

Auricles, described by Leonardo, 20.

Bacon, Lord Francis, 66.

Berengar of Carpi, $21,22$.

Bologna, Malpighi at, 70, 7 I.

Caius, John, 42.

Calvin, 35 .

Capillary blood-vessels, I, 7, 7 I, 74.

Circulation, lesser and greater, distinguished, 5 .

as first enunciated
by Harvey, 45.
described, I-Io.
Harvey's work on,
epitomised, 50-68.
meaning of term, 5.

College of Physicians, 43, 47 .

Columbus, Realdus, 36-37.

Corpuscles of blood, 72-75.

Egyptian ideas on pulse, ro.

Fabricius of Aquapendente, 38$4 \mathrm{r}, 43,60$.

" $\quad$ on respiration, $4 \mathrm{I}$.

Falloppius, Gabriel, 38.
Galen on anastomosis, 32, 33, 54 .

on heart, I 2-I 7 .

Galen's physiology, persistence of, $12,18,25,54$.

Galileo, 69 .

Geneva, Calvin at, 35 .

Greek, revived knowledge of, r8.

Harvey, 9, 43-68.

" experiments on bandaged arm, 58-62.

his death, 69 .

" in Cambridge, 42 .

" in London, $43 \mathrm{ff}$.

", in Padua, 43.

Harvey's Anatomical Dissertation, 47.

, first enunciation of circulation, 45 . handwriting, 43 .

", lecture notes, $43-46$.

", style, 43,48 .

Heart, structure of, 6 and throughout.

Hippocrates on pulse, ro.

Innate heat, $16,17,41,63,67$.

Latin, importance of, in sixteenth century, 24 .

Leeuwenhoek, Anthony van, 74.

Leonardo da Vinci, 19.

" on heart, $2 \mathbf{r}$.

", on respiration, 20.

Malpighi, 70.

on capillaries, 71 .

Methods, scientific, 67 .

Middle Ages, physiology in, I8. 
Padua, anatomy at, $24,37,38$, 42,43 . ancient theatre at, 43 .

Paris, anatomy at, 23.

Pulmonary artery $=$ arterial vein, $6,13,38,54,64$.

Pulse, I, ro.

Renaissance, 18 .

Royal Society publishes Leeuwenhoek's work, 74 . " , publishes Malpighi's work, $7 \mathrm{I}$.

Septum, supposed pores in, 6, I3, 14, 21, 25, 27, 28, 34, 37.
Servetus, 29-36.

" his martyrdom, 35 .

" on nature of blood, 3032.

Spirits, 15, 16, 33, 37, 63, 67 .

Swammerdam, Jacob van, 73 .

Valves, aortic, 6, $2 \mathrm{r}$.

, auriculo-ventricular, 6 .

", of veins, $3,40,60$.

", pulmonary, $6,21,53$.

Veins, distinction from arteries, 3.

Vena cava, $3,7,53$.

Venal artery $=$ pulmonary vein, I $4,15,20,25,38,64$. Vesalius, $23-28$.

" his criticism of Galen, $27,28$.

Vienne, Servetus at, 34 . 





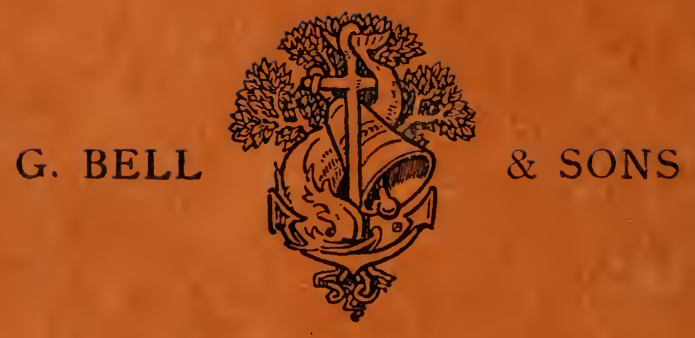

